\title{
PRAVA OSOBA S DUŠEVNIM SMETNJAMA U PSIHIJATRIJSKIM USTANOVAMA U REPUBLICI HRVATSKOJ - EMPIRIJSKA ANALIZA ${ }^{1}$
}

Prof. dr. sc. Velinka Grozdanic**

Doc. dr. sc. Dalida Rittossa**
UDK: 342.7-056.37(497.5)

Ur.: 11. rujna 2017.

Pr.: 8. listopada 2017.

Izvorni znanstveni rad

\section{Sažetak}

Danas, nakon mnogobrojnih znanstvenih spoznaja u području mentalnog zdravlja, sasvim je jasno da postoji izravna povezanost između poštovanja prava psihijatrijskih pacijenata i uvjeta smještaja u psihijatrijskim ustanovama s jedne strane te uspješnosti liječenja pacijenata, njihove deinstitucionalizacije, a time i destigmatizacije, s druge. No, posljednjih godina, sadržaji izvješća pučke pravobraniteljice i pravobraniteljice za osobe s invaliditetom te brojnih presuda Europskog suda za ljudska prava u slučajevima povodom pritužbi osoba s duševnim smetnjama, upozoravaju na loše uvjete smještaja i liječenja u psihijatrijskim ustanovama u Republici Hrvatskoj. Stoga se pokazalo opravdanim istražiti u kojoj mjeri psihijatrijski pacijenti ostvaruju svoja prava u psihijatrijskim ustanovama i u kakvim se uvjetima liječe. U tu svrhu, provedeno je istraživanje u Klinici za psihijatriju „Vrapče“, Psihijatrijskoj bolnici Rab, Neuropsihijatrijskoj bolnici „Dr. Ivan Barbot" Popovača i Psihijatrijskoj bolnici Ugljan, jedinim psihijatrijskim bolnicama u Republici Hrvatskoj koje u svom ustroju imaju i odjele za prisilno smještene neubrojive osobe po odluci kaznenog suda. Pritom su korištena dva upitnika, osnovni upitnik za ravnatelje psihijatrijskih ustanova $i$ anonimni upitnik za pacijente na uzorku od 80 ispitanika. Analiza rezultata dobivenih provedbom navedenih upitnika predmet je ovoga rada.

Ključne riječi: prava psihijatrijskih pacijenata, psihijatrijske ustanove, deinstitucionalizacija.

* Dr. sc. Velinka Grozdanić, redovita profesorica Pravnog fakulteta Sveučilišta u Rijeci; velinka@, pravri.hr

** Dr. sc. Dalida Rittossa, docentica Pravnog fakulteta Sveučilišta u Rijeci; dalida@pravri.hr

1 Ovaj rad je sufinancirala Hrvatska zaklada za znanost projektom IP-11-2013-2287 „Legal Status and Real Position of People with Mental Difficulties - Interdisciplinary Approach and European Perspectives" i Sveučilište u Rijeci potporama znanstvenim istraživanjima 13.08.1.3.02 „Interdisciplinarni pristup u istraživanju statusa osoba s duševnim smetnjama kroz prizmu konvencijskog prava“. 


\section{UVOD}

Posljednjih decenija ključna riječ koja se uporno ponavlja uz liječenje osoba s duševnim smetnjama je deinstitucionalizacija. Ona označava postupni prijelaz psihijatrijskih pacijenata iz institucija u zajednicu (obitelj ili posebne stambene zajednice za zajedničko stanovanje više osoba), uz osiguranu adekvatnu skrb kako bi funkcionirali u društvu. Naime, odavno se uvidjelo da se u psihijatrijskim bolnicama, posebno ako je riječ o prisilnim hospitalizacijama, ne postižu očekivani rezultati, te da su u njima psihijatrijski pacijenti izloženi različitim oblicima ugrožavanja njihovih temeljnih ljudskih prava. Stoga danas u svijetu postoje različiti modeli izvaninstitucionalnih rješenja (npr. američki, ${ }^{2}$ talijanski, ${ }^{3}$ nizozemski ${ }^{4}$ ) koji su

2 Ključni pravni akt koji je postavio normativni okvir za provođenje plana deinstitucionalizacije u kontekstu duševnoga zdravlja u SAD-u donesen je 1963. godine pod nazivom Mental Retardation Facilities and Community Mental Health Centers Construction Act. Iako su u ovom pravnom aktu osigurana sredstva za izgradnju i otvaranje 1500 centara duševnog zdravlja, stručnjaci upozoravaju da je početkom osamdesetih godina prošloga stoljeća djelovalo samo 754 centara. (Player, C. T.: Involuntary Outpatient Commitment: The Limits of Prevention, Stanford Law and Policy Review, vol. 26, 2015., str. 168.) Podbačaj navedenoga zakonodavnog akta $\mathrm{u}$ ostvarivanju zacrtanih ciljeva te prestanak federalnog financiranja usluga psihijatrijskog liječenja u državnim bolnicama, doveli su do velikog broja otpuštanja pacijenata iz bolnica bez da im se prethodno osigurala odgovarajuća skrb u zajednici. Američki model deinstitucionalizacije podbacio je i jer su se centri duševnog zdravlja koristili protivno svojoj svrsi. Naime, istraživanja su pokazala da su se u njih smještale osobe koje su se našle u nepovoljnom životnom razdoblju opterećene egzistencijalnim, socijalnim ili emocionalnim problemima, a ne osobe s duševnim smetnjama. (Isaac, R. J., Armat, V. C.: Madness in the Streets: How the Psychiatry and the Law Abandoned the Mentally Ill, Free Press, New York, 1990., str. 96.).

3 Idejni tvorac deinstitucionalizacije u Italiji, psihijatar Franco Basaglia, u jednom je intervjuu za talijanske medije zaključio kako „Nije bitno hoćemo li u budućnosti imati manji broj ludnica ili zatvorenih klinika već je bitna činjenica da smo mi sada pokušali učiniti nešto drukčije. Sada znamo da postoji drugi način pristupa problemu, čak i bez prisile.“ (Di Petta, G.: C'era una volta il manicomio: dal diario di un giovane medico, Edizioni Unversitarie Romane, Rim, 2014., str. 6.). Ova ideja predstavlja misao vodilju zakonodavne reforme započete s donošenjem Zakona 180/1978., kojim je Italija postala prva država na svijetu koja je ukinula psihijatrijske ustanove. Navedeni pravni akt uspostavio je regionalnu mrežu psihijatrijske pomoći za liječenje i praćenje pacijenata, punopravnih nositelja građanskih prava koje se tijekom tretmana nastoji integrirati u zajednicu. U mnogim dijelovima Italije Legge Basaglia zaživio je u praksi, no, u nekim područjima Zakon je bio izložen strogoj kritici, a politička i upravna inercija dovele su do bojkota primjene njegovih odredbi. (Norcio, B.: Care for Mentally Ill in Italy, BMJ, vol. 306, 1993., str. 1615.-1616.) Postupak deinstitucionalizacije u potpunosti je dovršen tek prije tri godine usvajanjem Zakona 81/2014, kojim se forenzički zatvorski odjeli zatvaraju i sele u „zajednice za izvršenje sigurnosnih mjera“.

4 Prvi početci deinstitucionalizacije nizozemskoga sustava duševnog zdravlja vežu se uz reforme koje je tridesetih godina prošloga stoljeća započeo psihijatar Querido. Naime, s nekoliko medicinskih sestara i psihijatara istomišljenika počeo je provoditi koncept socijalne psihijatrijske skrbi putujući zemljom i brinući se o osobama s psihičkim smetnjama nakon njihovog otpusta iz bolnice. Tijekom godina, postotpusna skrb o psihijatrijskim pacijentima uvelike se razvila, no pokretači ovog razvoja bile su samostalne inicijative unutar sustava duševnog zdravlja, a ne osmišljeni plan nadležnih državnih tijela. Na razvoj izvaninstitucionalne skrbi o osobama s duševnim smetnjama većinom su utjecala pravila o državnom financiranju 
u praksi polučili, ponekad dobre, a često i loše rezultate, a što je najviše ovisilo o razini kvalitete osigurane podrške osobama izvan institucijske skrbi. Unatoč za sada „siromašnim“ rezultatima u provedbi, danas, ne postoje nikakve dvojbe u ispravnost ideje deinstitucionalizacije koja polazi od autonomije, samoodređenja i prava na izbor načina života psihijatrijskih pacijenata. Štoviše, ova plemenita ideja o skrbi osoba s duševnim smetnjama u zajednici, našla je svoje mjesto u brojnim međunarodnim i nacionalnim dokumentima, ${ }^{5}$ zbog čega je njezina realizacija postala obvezujuća za vladajuće društvene strukture.

Ipak, treba imati na umu da je od same ideje deinstitucionalizacije do njezine potpune realizacije dug put. Naime, riječ je o zahtjevnom procesu pred kojim postoje brojne prepreke $\mathrm{i}$ to na strani društva (financijske, osobito u prvoj etapi paralelnog postojanja i ustanova i stambenih zajednica, kadrovske, organizacijske itd.) i na strani pacijenata (prilagodba na nove uvjete i način života izvan psihijatrijske ustanove koja je osobito otežana kod dugotrajnih liječenja u psihijatrijskim ustanovama). Jasno je da je riječ o procesu za čije će ostvarivanje biti potrebne godine, a možda i desetljeće. Iako deinstitucionalizacija obuhvaća sve korisnike institucionalnog smještaja (djecu bez roditeljske skrbi, s poremećajima u ponašanju, stare i nemoćne osobe) ova pesimistična rečenica posebno se odnosi na osobe s duševnim smetnjama i to ponajprije zbog izrazite društvene stigme kojom su one obilježene. Među njima najveću stigmu društvene opasnosti trpe osobe s duševnim smetnjama koje su prisilno smještene u psihijatrijske ustanove odlukom suda. Ovdje je riječ o neubrojivim osobama za koje je u kaznenom postupku utvrđeno da su u stanju neubrojivosti počinile protupravnu radnju propisanu u Kaznenom zakonu kao kazneno djelo i da postoji vjerojatnost da bi zbog težih duševnih smetnji, zbog kojih je i nastupila njihova neubrojivost, mogle ponovno počiniti teže kazneno djelo te da je za otklanjanje te opasnosti potrebno njihovo liječenje u psihijatrijskoj ustanovi. Isto tako prisilnoj hospitalizaciji podliježu i, tzv. nedelinkventi, dakle, osobe s težim duševnim smetnjama koje nisu počinile nikakvu protupravnu radnju, ali koje zbog svojih smetnji ozbiljno i izravno ugrožavaju vlastiti ili tuđi život, zdravlje ili sigurnost. Stoga nema sumnje da će za tu kategoriju osoba (tzv. forenzički pacijenti) psihijatrijske ustanove i dalje biti mjesto u kojem će provoditi određeni dio svoga života. ${ }^{6}$

i zapošljavanju osoblja, no ona su dovela do rivalstva među psihijatrijskim bolnicama i jedinicama izvaninstitucionalne skrbi. Nizozemski model uvelike opterećuje činjenica da se interesi pojedinačnih skupina koje pružaju usluge osobama s duševnim smetnjama razlikuju od općih društvenih interesa što nikako nije dobro rješenje. Giel, R.: The Jigsaw Puzzle of Dutch Mental Health Care, International Journal of Mental Health, vol. 16, br. 1/2, 1987., str. 152.156.; Van Hoof, F. i dr.: The Role of National Policies and Mental Health Care Systems in the Development of Community Care and Community Support: An International Analysis, Journal of Mental Health, vol. 24, br. 4, 2015., str. 202.-207.

5 V. Grozdanić, V. (ur.): Komentar Zakona o zaštiti osoba s duševnim smetnjama, Pravni fakultet Sveučilišta u Rijeci, Rijeka, 2015., str. 319.-373.; Perlin, M. L.: International Human Rights and Institutional Forensic Psychiatry: The Core Issues, objavljeno u: Völlm, B., Nedopil, N. (ur.): The Use of Coercive Measures in Forensic Psychiatric Care, Legal, Ethical and Practical Challenges, Springer International Publishing, Cham, 2016., str. 9.-29.

6 Pored forenzičkih pacijenata u psihijatrijskim ustanovama bez svoje volje smještene su i osobe $\mathrm{s}$ težim duševnim smetnjama koje nisu sposobne dati pristanak, pa pisani pristanak umjesto njih 
Slijedom navedenoga, pitanje zaštite prava osoba s duševnim smetnjama smještenih u psihijatrijske ustanove ostaje i dalje iznimno važno. Može se reći da je potreba za sustavnom analizom uvjeta lišavanja slobode i nadzorom onih koji te uvjete kreiraju usko vezana uz osvješćivanje ideje o važnosti ljudske slobode i da su mehanizmi izvanjske kontrole i zaštite zatvaranih relativno kasno uvedeni u ustanove u kojima se osobe lišavaju slobode. Prvi koraci u ovome smjeru poduzeti su tek krajem osamnaestog stoljeća, i to očekivano, radi istraživanja stanja u nekim europskim zatvorima. $^{7}$ Zatvori su se, naime, počeli percipirati kao mjesta izvršavanja kazne lišenja slobode počinitelja zbog počinjenoga kaznenog djela, a kazna zatvaranjem kao opravdana punitivna reakcija društva. ${ }^{8}$

Za razliku od zatvora, stručna i šira javnost psihijatrijske ustanove ponajprije percipira kao ustanove organizirane u sustavu bolničkog liječenja, a prisilnu hospitalizaciju kao postupak nužan za otklanjanje opasnosti psihijatrijskog pacijenta putem medicinskoga tretmana. Drugim riječima, činjenica da se prisilnim zadržavanjem i smještajem u psihijatrijsku ustanovu osobi s duševnom smetnjom oduzima i sloboda, pritom se ne percipira ili joj se pridaje sekundarni značaj. ${ }^{9}$ No, unatoč tomu, ipak se zadnjih godina, i to putem međunarodnih instrumenata, snažno promiče ideja da je prisilna hospitalizacija jedan od oblika oduzimanja prava na slobodu. ${ }^{10}$ Svaka uskrata

daju osobe od njihovog povjerenja ili njihovi zakonski zastupnici. Više o svim kategorijama smještaja u psihijatrijsku ustanovu v. Grozdanić, V. (ur.), op. cit., str. 35., 113.-118.

7 U penološkoj literaturi John Howard spominje se kao jedan od prvih autora koji je istražio uvjete i opisao sliku stanja u zatvorima u Engleskoj i Walesu. (Howard, J.: The State of Prisons in England and Wales with Preliminary Observations and an Account of Some Foreign Prisons and Hospitals, William Eyres, Warrington, 1777.) Prvu analizu uvjeta u njemačkim zatvorima pružio je Heinrich Balthasar Wagnitz 1791. godine, a penološka znanost pamti ga kao jednog od prvih zagovaratelja prava zatvorenika. (Wagnitz, H. B.: Historische Nachrichten und Bemerkungen über die merkwürdigsten Zuchthäuser in Deutschland: Nebst einem Anhange über die zweckmässigste Einrichtung der Gefängnisse und Irrenanstalten, Johann Jacob Gebauer, 1791.)

8 U prilog izrečenom ide i Burrenov zaključak kako „tek kada su ljudi naučili cijeniti slobodu, oduzimanje slobode priznaje i prijestupnik kao jedinu kaznu.“ Burren, E.: Theorien der Strafe und Probleme des modernen Strafvollzuges, Kriminalistisches Institut des Kantons Zürich, Lenzburg, 1963., str. 2.

9 Tako je tijekom kaznenoga postupka na Općinskom sudu u Rijeci, u tzv. slučaju Lopača, Općinsko državno odvjetništvo vodilo kazneni postupak protiv okrivljene zbog počinjenja kaznenog djela nesavjesnog liječenja (čl. 181. KZ/11), a ne i protupravnog oduzimanja slobode (čl. 136. KZ/11), unatoč tomu što su činjenice slučaja ukazivale na propuste psihijatrijske ustanove da obavijesti Županijski sud u Rijeci o prisilnom zadržavanju oštećenice nakon stjecanja njezine punoljetnosti i gubitka roditeljskih prava skrbnika što je za sobom automatski povlačilo prestanak smještaja po pristanku zakonskog zastupnika.

10 O povredi prava na slobodu i sigurnost iz članka 5. Europske konvencije za zaštitu ljudskih prava i temeljnih sloboda o prisilnom zatvaranju psihijatrijskih bolesnika već postoji bogata sudska praksa Europskog suda za ljudska prava. Nadzor nad uvjetima u psihijatrijskim ustanovama u Republici Hrvatskoj redovito obavlja i Europski odbor za sprječavanje mučenja i neljudskog ili ponižavajućeg postupanja ili kažnjavanja i izvješća dostavlja nadležnim državnim tijelima. Zadnji takav nadzor članovi Odbora obavili su 14. ožujka 2017. godine nad radom djelatnika u Psihijatrijskoj bolnici Vrapče, Klinici za psihijatriju - KBC Zagreb i Psihijatrijskoj bolnici za djecu i mladež u Zagrebu (The Council of Europe: The CPT Visits Croatia, objavljeno na: 
slobode pojedinca od strane državnih tijela, neovisno o punitivnim ili terapijskim svrhama, mora zadovoljiti osnovne materijalne i procesne zahtjeve kako bi se smatrala opravdanom i u skladu sa zakonom. Pritom treba imati na umu pravilo da što je ograničenje slobode teže, to je veća potreba za pojačanim zakonodavnim garancijama zaštite prava onih koje se zatvara. Ujedno, zatvaranje nikada ne smije biti samom sebi svrha, već pogodan put za ostvarivanjem zakonom propisanoga cilja koji je u konačnici, neovisno o pravnoj osnovi smještaja, uvijek usmjeren na povrat pojedinca u zajednicu. ${ }^{11}$ Danas se može reći kako je istaknuta zakonitost općeprihvaćeni normativni standard i civilizacijski doseg. Ispunjavanje ovoga dosega u zatvorenoj strukturi psihijatrijskih ustanova zasigurno ovisi o priznavanju prava psihijatrijskih pacijenata i uvjetima njihova liječenja u psihijatrijskim ustanovama. Stoga se čini važnim i zanimljivim istražiti kakvi uvjeti postoje u našim psihijatrijskim ustanovama u kojima se prisilno hospitaliziraju i forenzički pacijenti i poštuju li se i u kojoj mjeri njihova prava zagarantirana brojnim nacionalnim i međunarodnim dokumentima.

\section{TEMELJNE ODREDNICE PROVEDENOGA EMPIRIJSKOG ISTRAZ̆IVANJA}

Istraživanje o poštovanju i osiguravanju temeljnih prava psihijatrijskih pacijenata izričito propisanih u Zakonu o zaštiti osoba s duševnim smetnjama (nadalje ZZODS) ${ }^{12}$ i o uvjetima njihova liječenja, provedeno je u četiri psihijatrijske ustanove, i to $u$ Klinici za psihijatriju „Vrapčc“ (nadalje Vrapče), Psihijatrijskoj bolnici Rab (nadalje Rab), Neuropsihijatrijskoj bolnici „Dr. Ivan Barbot“ Popovača (nadalje Popovača) i Psihijatrijskoj bolnici Ugljan (nadalje Ugljan). Navedene bolničke institucije jedine su četiri psihijatrijske ustanove u Republici Hrvatskoj u kojima se pored ostalih psihijatrijskih pacijenata (dobrovoljno smještenih, smještenih bez pristanka te prisilno smještenih po odluci civilnoga suda), prisilno smještavaju i liječe neubrojive osobe po odluci kaznenog suda. ${ }^{13}$

\subsection{O psihijatrijskim ustanovama uključenima u istraživanja}

Davne 1873. godine, donošenjem Zakonskoga članka o ustrojavanju javne ludnice za obseg Hrvatske i Slavonije, postavljeni su normativni temelji za otvaranje

$<$ http://www.coe.int/en/web/cpt/-/the-cpt-visits-croatia>, zadnji put posjećeno 10. svibnja 2017.).

11 U svojoj opširnoj „Osnovi o podignuću i ustrojstvu zemaljske ludnice“ upućenoj namjesničkom vijeću Schlosser je davne 1865. godine istaknuo kao jedno od temeljnih načela da „Zavod ne smije služiti samo bezuspješnom pozatvaranju luđaka, nego treba da odgovara načelima čovječnosti i da posluži izlječenju ovih nesretnika“. Glesinger, L.: Povijest psihijatrije u Hrvatskoj, Pretisak doktorske disertacije, objavljeno u: Pećina, M. i Fatović-Ferenčić, S. (ur.): Ludnica i lučbarnica, Razvoj laboratorija u psihijatrijskoj bolnici, Rasprave i građa za povijest znanosti, Knjiga 12, Hrvatska akademija znanosti i umjetnosti, Zagreb, 2012., str. 80.

12 Zakon o zaštiti osoba s duševnim smetnjama, NN 76/14.

13 Pravilnik o listi psihijatrijskih ustanova za prisilni smještaj neubrojivih osoba i psihijatrijskih ustanova u kojima se neubrojive osobe liječe na slobodi, NN 76/14. 
psihijatrijske ustanove koja danas nosi naziv Klinika za psihijatriju „Vrapče““. ${ }^{14}$ Nakon otvaranja, ova ustanova započinje svoj rad pod nazivom ,Zavod za umobolne Stenjevec" i zadržava ga sve do 1933. godine kada joj je službeno dodijeljen naziv „Državna bolnica za duševne bolesti Stenjevec“. U narednom razdoblju mijenjala su se imena ustanove sve do kraja 2010. godine kada joj je dodijeljen naziv klinike. Formalne promjene naziva jedne od ustanova s najdužom praksom liječenja osoba $\mathrm{s}$ duševnim smetnjama u nas, osim izmjena u ustroju, odražavale su i napredak u praksi liječenja bolesnika i psihijatrijske struke. Klinika za psihijatriju „Vrapče“ prošla je tako dalek put od azilske ustanove s odjelima ,za nemirne i mirne muškarce, nemirne i mirne žene, nečiste muškarce i nečiste žene..." do klinike s dvanaest zavoda, dvadeset i pet odjela te dnevnom bolnicom. ${ }^{15} \mathrm{U}$ razdoblju od gotovo 150 godina, u njoj su se događali usponi i padovi koji su pratili psihijatrijsku struku. Danas, na polazištima ideje o deinstitucionalizaciji u viziji budućeg razvoja psihijatrijske ustanove „Vrapče“ predviđa se smanjenje broja kreveta za stacionarno liječenje pacijenata i njezino daljnje profiliranje za edukaciju i specijalizaciju psihijatrijskog kadra i znanstvenog istraživanja. ${ }^{16}$

Bilo je potrebno nešto više od pola stoljeća da se na našim prostorima pod okriljem države osnuje nova ustanova u kojoj bi se pružala skrb i medicinska pomoć osobama s duševnim patnjama. Godine 1934., na nekadašnjem feudu grofova Erdödya, oformljeno je Odjeljenje Beogradske državne bolnice za duševne bolesti za kronične bolesnike u Moslavini - Popovača. Uspostava ovog odjeljenja bila je prvi korak u ispunjavanju vizije liječnika Ivana Barbota o humanom tretmanu duševnih bolesnika u kojem uz medicinski pristup ključnu ulogu imaju i okolišni uvjeti. ${ }^{17}$ Nekada izdvojena depandansa beogradske ustrojbene jedinice, Neuropsihijatrijska bolnica „Dr. Ivan Barbot“ Popovača danas je samostalna psihijatrijska ustanova u čiji je naziv od 1974. godine uvršteno i ime njezinoga osnivača i tvorca. Iako je, kao i sve druge psihijatrijske ustanove, ustrojena na ideji institucionalizacije, u ovoj psihijatrijskoj ustanovi učinjen je kvalitativni pomak u smjeru prihvaćanja ideje o provođenju izvanbolničke psihijatrijske djelatnosti osnivanjem dnevne bolnice. $\mathrm{U}$ individualnom radu $\mathrm{s}$ pacijentima interdisciplinarni tim „,bolnice u bolnici“ nastoji u praksi ostvariti naprednu ideju o smanjenju stacionarnog liječenja putem uključivanja društvene zajednice u terapijsko liječenje osoba s duševnim smetnjama u tradicionalnoj, institucionalnoj psihijatriji svedenoj na dnevni okvir. ${ }^{18}$

14 Zakonski članak br. 58. o ustrojavanju javne ludnice za obseg Hrvatske i Slavonije, Sbornik zakonah i naredabah valjanih za Kraljevinu Hrvatsku i Slavoniju, godina 1873., komad XIX.

15 Mimica, N.: Otvorena Spomen-biblioteka u Klinici za psihijatriju Vrapče, Mef.hr: list Medicinskog fakulteta Sveučilišta u Zagrebu, vol. 30, br. 2, 2011., str. 105.

16 Jukić, V.: Bolnica Vrapče kao odraz društvene stvarnosti: pogled jednog ravnatelja, objavljeno u: Pećina, M. i Fatović-Ferenčić, S. (ur.), op. cit., str. 96.

$17 \mathrm{O}$ vizionarskom istupu Barbota najbolje govori njegova poznata rečenica: „Nipošto ne razumijem da tamo gdje su nekada živjeli grofovi, ne bi danas mogao živjeti duševni bolesnik, liječnik i personal, tim prije što su takvi dvorci većinom u vrlo zdravom kraju, okruženi parkovima..." Kovač, M.: Sedamdeset i pet godina neuropsihijatrijske bolnice, objavljeno na: $<$ http://www.psihoportal.com/index.php/hr/en/vijesti/416-75-godina-neuropsihijatrijske-bolnice>, zadnji put posjećeno 10. svibnja 2017.

18 Poredoš Lavor, D. i dr.: Dnevna bolnica: društveno-medicinska sadašnjost i budućnost, Ljetopis 
U vrijeme osnivanja psihijatrijskih bolnica u Rabu i Ugljanu ideja o obvezi države da organizira odgovarajuću skrb i liječenje osoba s duševnim smetnjama uvelike je zaživjela. Navedene bolnice nastale su u sklopu programa rasterećenja prenapučenih, operativnih bolnica u Hrvatskoj 1955. godine, a prvi pacijenti za koje je osiguran smještaj u novootvorenim bolnicama pristigli su upravo iz Vrapča i Popovače. ${ }^{19}$ Osim što dijele povijesne okolnosti nastanka, psihijatrijske bolnice u Rabu i Ugljanu povezuje i jedinstveno arhitektonsko rješenje. Naime, obje su smještene u obnovljene paviljone talijanskih vojnih logora u otočkom mediteranskom okruženju. Djelomična izoliranost uzrokovana lokalitetom utjecala je na rad psihijatrijskih bolnica svih ovih godina. No, kako bi se posljedice dislokacije barem donekle umanjile i preobratile u prednost, u psihijatrijskim ustanovama uvedeni su posebni tretmanski koncepti. Tako je u Rabu primijenjen pristup arhitektonskog uređenja bolnice kao centra za oporavak duše i tijela (wellness centar) pacijenata čije se potrebe liječenja ne mogu zadovoljiti izvaninstitucionalno ${ }^{20}$ dok Ugljan već dugi niz godina funkcionira kao otvorena bolnica „,bez ograde“ kako bi se zadržala povezanost osoba s duševnim smetnjama s primarnom zajednicom i olakšala njihova rehabilitacija. U nastojanjima da se dodatno „olabave“ strogi institucionalni okviri i odgovori na izazove koje pred bolničku upravu postavlja koncept deinstitucionalizacije, u obje bolnice djeluje i dnevna bolnica. U dnevnoj bolnici na Ugljanu s Hrvatskim zavodom za javno zdravstvo u 2017. godini ugovoreno je 30, a na Rabu 35 mjesta. ${ }^{21} \mathrm{Uz}$ sva stremljenja i konkretne pomake u pravcu ostvarivanja prijelaza psihijatrijskih pacijenata iz bolnica u zajednicu, ovi podatci upućuju na zaključak da proces deinstitucionalizacije teče sporo i da na tom putu postoje mnogobrojne prepreke. Primjerice, suočeni s teškoćom dolazaka pacijenata na otok i njihovim negativnim iskustvima zbog stigmatizacije, ravnateljstvo psihijatrijske ustanove na Ugljanu svoju dnevnu bolnicu premješta nakon samo dvije godine rada u Zadar.

\subsection{Upitnici - metodološko modeliranje i prilagodba svrsi istraživanja}

$\mathrm{U}$ provođenju istraživanja $\mathrm{u}$ opisanim psihijatrijskim ustanovama korištena su dva upitnika. Prvi upitnik ispunjavali su ravnatelji psihijatrijskih ustanova. Riječ je o standardiziranom upitniku, ${ }^{22}$ nešto izmijenjenom i prilagođenom potrebama provođenja istraživanja u psihijatrijskim bolnicama te je dobiven anketni obrazac

socijalnog rada, vol. 15, br. 2, 2008., str. 323.-324.

19 Jukić, V., op. cit., str. 91.

20 Šendula-Jengić, V., Juretić, I. i Hodak, J.: Psychiatric Hospital - From Asylums to Centres for Mind-Body Wellness, Collegium Antropologicum, vol. 35, br. 4, 2011., str. 978.-988.

21 Hrvatski zavod za zdravstveno osiguranje, Ugovoreni sadržaji bolničke zdravstvene zaštite za 2017. godinu, Postelje, specijalističke ordinacije, dijagnostičke jedinice mjesta dnevne bolnice 2017., objavljeno na: <http://www.hzzo.hr/>, zadnji put posjećeno 10. svibnja 2017.

22 Budući da su forenzički odjeli zatvoreni odjeli u posebnom režimu unutar psihijatrijske ustanove, sastavljen je osnovni upitnik namijenjen ravnateljima prema standardiziranom upitniku o uvjetima života u kaznionicama u kojima se izvršava kazna zatvora od pet i više godina Long Term Imprisonment and the Issue of Human Rights in Member States of the European Union. 
od trideset i četiri pitanja. Pitanja su sastavljena kako bi se obradile četiri posebne cjeline. Prva cjelina sadržavala je opća pitanja o kapacitetima i karakteristikama smještaja bolesnika (broj pacijenata po kategorijama smještaja, spolu i dobi). U drugu skupinu uvrštena su pitanja o uvjetima smještaja (broj soba i kriteriji smještaja u jednokrevetnim i zajedničkim sobama, sanitarni čvorovi, krevetnina, higijenske potrepštine, održavanje čistoće, prehrana, primanje posjeta, zaposleno osoblje). Isto tako u upitnik su uvrštena i pitanja o terapijskom radu i programima s pacijentima. Posebna grupa pitanja sastavljena je kako bi se ispitalo poštuju li se u pojedinoj ustanovi temeljna načela i temeljna prava pacijenata prema ZZODS-u (upoznavanje s temeljnim pravima iz ZZODS-a, dostupnost ovoga pravnog akta osoblju i pacijentima, pristanak na medicinske postupke, pristanak na biomedicinska istraživanja, primjena mjera prisile, posjedovanje osobnih predmeta, pristup informacijama, primanje naknade za rad, podnošenje zahtjeva i pritužbi te komuniciranje s odvjetnikom). Kako je jedno od temeljnih ciljeva istraživanja analiza postojećeg stanja u psihijatrijskim ustanovama, ali i predlaganje konkretnih mjera za poboljšanje životnih uvjeta pacijenata i radnih uvjeta zaposlenika, u upitniku je predviđen slobodan prostor u kojem su ravnatelji mogli iznijeti svoje prijedloge za unaprjeđenje rada u njihovoj ustanovi i izmjene i dopune ZZODS-a.

Drugi je upitnik ${ }^{23}$ bio anoniman i njega su ispunjavali pacijenti smješteni $u$ istraživanim psihijatrijskim ustanovama, iznoseći osobna iskustva o boravku, liječenju i zaštiti njihovih prava u tim ustanovama. Upitnik za pacijente predstavljao je temeljni istraživački alat jer se od njega očekivao odgovor na ključno pitanje - ostvaruju li uistinu se pozitivne zakonodavne ideje o zaštiti i unaprjeđivanju prava i stvarnoga statusa ovih osoba ili i dalje prevladava formalistički pristup zbog kojega nije ni moguće ukloniti brojne barijere koje stoje na putu punopravnoga priznavanja prava osoba s duševnim smetnjama u društvu. ${ }^{24}$ Procjena vlastitoga položaja ocjenjivanjem uspješnosti ostvarivanja pojedinoga prava u izdvojenom okruženju psihijatrijske ustanove samih pacijenata čini se pogodnom metodom za iznalaženje odgovora na uočenu dvojbu. ${ }^{25}$ Kako bi se dobili iskreni odgovori upitnik je bio anoniman, a načinom

23 Upitnik za pacijente sastavljen je prema predlošku Svjetske zdravstvene organizacije Taking the Human Rights Temperature of Your Community koji se $\mathrm{u}$ istraživačkim krugovima uobičajeno koristi za ispitivanje kvalitete ljudskih prava u pojedinoj zajednici ili ustanovi. V. o tome Flowers, N.: The Human Rights Education Handbook, Effective Practices for Learning, Action, and Change, The Human Rights Resource Center University of Minnesota, The Stanley Foundation, 2000., str. 90.-94.

24 Gostin i Gable tako upozoravaju da se u mnogim zemljama ne poštuju ljudska prava osoba s duševnim smetnjama. (Gostin, L., O. i Gable, L.: The Human Rights of Persons with Mental Disabilities: A Global Perspective on the Application of Human Rights Principles to Mental Health, Maryland Law Review, vol. 63, 2004., str. 21.); Poreddi i grupa autora smatraju da su stigmatizacija, dodjeljivanje statusa trajnog invaliditeta, netolerancija i nemogućnost prosvjeda protiv izrabljivanja glavni uzroci pojačane zabrinutosti zbog nemogućnosti ostvarivanja ljudskih prava psihijatrijskih pacijenata. (Poreddi, V. i dr.: People with Mental Illness and Human Rights: A Developing Countries Perspective, Indian Journal of Psychiatry, vol. 55, br. 2, 2013., str. 118.)

25 U provedenom upitniku zadržana je struktura, bodovna skala i dio pitanja iz predloška Svjetske zdravstvene organizacije. Kako bi se anketni obrazac prilagodio hrvatskom kontekstu, veći dio 
provođenja ankete osigurana je anonimnost ispitanika. Tako su na dan ispitivanja u svakoj psihijatrijskoj ustanovi slučajnim odabirom, među pacijentima koji su bili sposobni sudjelovati u istraživanju i na to su dobrovoljno pristali, formirane ispitivačke grupe. Istraživanje je provedeno u posebnim prostorijama u koje su dovedeni pacijenti s različitih odjela i obavljeno je samo uz prisutnost ispitivača.

Upitnik je sadržavao 25 pitanja koja su razvrstana u četiri različite skupine prema njihovom izvoru i sadržaju. U prvu skupinu uvrštena su pitanja preuzeta iz izvornog upitnika Taking the Human Rights Temperature of Your Community kojima se ispitivala kakvoća uživanja prava ispitanika iz UN-ove Opće deklaracije o ljudskim pravima. ${ }^{26}$ Druga skupina pitanja odražavala je temeljna načela koja su oblikovala sva normativna rješenja pa tako i prava osoba s duševnim smetnjama iz ZZODS-a. Temeljna načela vezivno su tkivo cijeloga Zakona i pružaju opći kontekst zaštite prava psihijatrijskih pacijenata. U tom segmentu istraženo je u kojoj se mjeri poštuje dostojanstvo, sloboda i prava ispitanika i štite li se oni od ponižavanja i nasilničkoga ponašanja. Zatraženo je i njihovo mišljenje koliko često se od njih traži pisani pristanak na provođenje medicinskih postupaka. Osim što se istražilo ostvarivanje prava na najvišoj razini načela, ispitala se i primjena pojedinačnih prava izvedenih iz proklamiranih načela (pravo da se osobu upozna sa svojim pravima tijekom prijema u psihijatrijsku ustanovu te s razlozima i ciljevima smještaja, pravo na uvid u medicinsku dokumentaciju, podnošenje pritužbi, novčanu naknadu za rad obavljen za psihijatrijsku ustanovu, biračko pravo, pravo na redovito primanje posjeta, slanje i primanje pisama i paketa te slobodno korištenje mobitela ili telefona, pravo praćenja radijskih i televizijskih programa, pravo na posjedovanje osobnih predmeta i na sudjelovanje u vjerskim i kulturnim aktivnostima te pravo na osiguranu podršku za život u zajednici). Nadalje, kako bi se ispitale različite varijable i pokušale dovesti u vezu s dobivenim odgovorima o osobnom iskustvu u ostvarivanju vlastitih prava, u upitnik su uvrštena i standardna pitanja o socio-demografskom statusu ispitanika (spol, dob, zanimanje, obiteljski status) te pravna osnova i trajanje smještaja. ${ }^{27}$

pitanja sastavljen je prema načelima i pravima iz ZZODS-a koja su ocijenjena kao bitna za dobivanje uvida u uspješnost zaštite i samoostvarivanje temeljnih ljudskih prava psihijatrijskih bolesnika. Ovakvo sadržajno modificiranje upitnog lista uobičajeno je metodološko rješenje u istraživanjima o razini poštovanja prava osoba s duševnim smetnjama.

26 Čl. 2.-3., 5., 7., 12., 17., 19.-22., 23., 26.-29. Opće deklaracije o ljudskim pravima, NN-MU $12 / 09$.

27 Ova grupa pitanja bila je formulirana tako da su ispitanicima uz svako od prava bili ponuđeni odgovori na zaokruživanje: nikad, rijetko, često, uvijek i ne znam, a svaki od tih odgovora nosio je određenu bodovnu vrijednost $($ nikad $=1$; rijetko $=2$; često $=3$; uvijek $=4$; ne znam $=$ 0). Tako je najveći broj bodova koji se mogao ostvariti u pojedinačnom upitniku iznosio 100 , što bi prema metodološkoj skali značilo da ispitanik smatra kako se u navedenoj psihijatrijskoj ustanovi u potpunosti (100 \%) poštuju njegova prava. Dva pitanja čestice o osnovnim osobnim podatcima ispitanika imala su ponuđene odgovore, a u ostalima je odgovor podatak trebalo upisati na određeno mjesto. 


\section{PRIKAZ REZULTATA ISTRAŽIVANJA S KOMENTARIMA}

\subsection{Rezultati i analiza osnovnih upitnika za ravnatelje}

Odgovori ravnatelja psihijatrijskih ustanova iskazani u osnovnim upitnicima za ravnatelje, daju obilje preciznih i korisnih podataka koji mogu poslužiti kao solidan temelj za stjecanje dojma o uvjetima smještaja, boravka i liječenja psihijatrijskih pacijenata u istraživanim psihijatrijskim ustanovama.

Tablica 1. Smještajni kapaciteti, popunjenost ustanova i načini smještaja pacijenata

\begin{tabular}{|l|c|c|c|c|c|c|}
\hline \multicolumn{2}{|c|}{} & \multicolumn{5}{|c|}{ Broj pacijenata na dan provođenja istraživanja } \\
\hline $\begin{array}{c}\text { Psihijatrijska } \\
\text { ustanova }\end{array}$ & $\begin{array}{c}\text { Raspoloživa } \\
\text { mjesta }\end{array}$ & $\begin{array}{c}\text { Ukupan } \\
\text { broj } \\
\text { pacijenata }\end{array}$ & $\begin{array}{c}\text { Dobrovoljni } \\
\text { smještaj }\end{array}$ & $\begin{array}{c}\text { Smještaj } \\
\text { bez } \\
\text { pristanka } \\
\text { (zamjenski } \\
\text { pristanak) }\end{array}$ & $\begin{array}{c}\text { Prisilni } \\
\text { smještaj } \\
\text { odlukom } \\
\text { suda (civilni } \\
\text { prisilni) }\end{array}$ & $\begin{array}{c}\text { Neubrojive } \\
\text { osobe }\end{array}$ \\
\hline Popovača & 699 & 547 & 351 & 2 & 10 & 184 \\
\hline Rab & 430 & 334 & 258 & 38 & 3 & 35 \\
\hline Ugljan & 404 & 409 & 368 & 10 & 0 & 31 \\
\hline Vrapče & 881 & 643 & 524 & 49 & 8 & 62 \\
\hline
\end{tabular}

Iz tablice 1. vidljivo je da psihijatrijska ustanova Vrapče s ukupno 881 raspoloživim mjestom ima najjači smještajni kapacitet. Zatim slijedi Popovača sa 699 raspoloživih mjesta, pa Rab i Ugljan koji zajedno imaju manje raspoloživih mjesta od Vrapča. Stoga ne iznenađuje da je na dan provođenja istraživanja najviše pacijenata bilo u Vrapču, a najmanje na Rabu.

U svim ustanovama, od ukupnoga broja pacijenata, najveći je broj smješten dobrovoljno, a kako je riječ o jedinim ustanovama u Republici Hrvatskoj u kojima se prisilno smještaju neubrojive osobe po odluci kaznenoga suda, očekivano, u svim navedenim ustanovama borave i neubrojive osobe. Tako je više od $50 \%$ neubrojivih osoba (točno 58,9 \%) smješteno u Popovači koja ima najbolje prostorne i sigurnosne uvjete za smještaj tih osoba. Naime, u Popovači na Zavodu za forenzičku psihijatriju zbog sigurnosnih uvjeta raspoređen je veći broj djelatnika, a na odjelima je ugrađen i video nadzor te se za pregled koristi detektor metala. Pored toga postoji i soba za izolaciju (za bolesnike koji mogu ugroziti sebe ili druge), a pacijenti imaju alarmni sustav za uzbunjivanje. Prema podacima iz upitnika proizlazi da i u psihijatrijskim ustanovama u Vrapču i Ugljanu postoji odjel zadovoljavajuće sigurnosti. Jedino u psihijatrijskoj ustanovi na Rabu ne postoji odjel zadovoljavajuće sigurnosti, odnosno postoji odjel niske razine sigurnosti uz kontinuirano prisutan deficitaran kadar.

U svim psihijatrijskim ustanovama smješteni su i žene i muškarci, bilo na odvojenim odjelima, bilo u odvojenim sobama na istim odjelima. Međutim nema odvajanja tijekom terapijskih aktivnosti ili u slobodno vrijeme. Ono što posebno dolazi do izražaja je veći broj muškaraca u odnosu na žene u svim psihijatrijskim ustanovama. Tako su u Popovači od ukupno smještenih osoba 26,1 \% žene, na Rabu 
26,9 \%, u Vrapču 33,1 \% te na Ugljanu tek 0,7 \%. Ovaj podatak o bitno manjem broju žena u psihijatrijskim ustanovama odstupa od rezultata brojnih istraživanja koja pokazuju suprotne rezultate. ${ }^{28}$

Vezano uz dobne razlike među pacijentima, treba naglasiti da se niti u jednoj od ovih ustanova ne nalaze djeca, odnosno osobe mlađe od osamnaest godina. To je u skladu s odredbom ZZODS-a po kojoj se djecu koju je potrebno liječiti u psihijatrijskoj ustanovi mora smjestiti i liječiti odvojeno od punoljetnih osoba (čl. 10., st. 2.) i to u psihijatrijskim ustanovama koje su određene Pravilnikom o listama psihijatrijskih ustanova koje ispunjavaju uvjete za smještaj i liječenje djece odvojeno od punoljetnih osoba. ${ }^{29}$ Suprotno djeci, osobe starije životne dobi česti su stanari psihijatrijskih ustanova. Naime, iako je starost normalan fiziološki proces, obilježen velikim individualnim razlikama, gerijatrijsku dob prate i brojne negativne promjene koje stare osobe čine osjetljivima za mnoge, ne samo fizičke već i psihičke bolesti. U tom kontekstu ne iznenađuju podatci da su na dan provođenja istraživanja $u$ psihijatrijskim ustanovama među pacijentima, u velikom broju bile prisutne osobe starije životne dobi, odnosno osobe starije od 65 godina. Tako je u Vrapču među pacijentima čak 29,9 \% bilo osoba starije životne dobi, u Popovači 21,9 \%, na Rabu $12 \%$ i na Ugljanu $0,7 \%$.

Vezano uz smještajne uvjete, sve četiri psihijatrijske ustanove imaju višekrevetne sobe. Maksimalni je broj osoba u zajedničkoj sobi u Popovači i na Rabu šest, na Ugljanu osam, a u Vrapču deset. Dobiveni podatak zabrinjava jer bolnički kapaciteti smještaja pacijenata u zajedničkim prostorijama nisu u skladu s važećim Pravilnikom o minimalnim uvjetima u pogledu prostora, radnika i medicinsko-tehničke opreme za obavljanje zdravstvene djelatnosti, prema kojem bolesnička soba može imati najviše četiri bolesnička kreveta. ${ }^{30}$ Grupiranje u zajedničke sobe obavlja se prema medicinskim i sigurnosnim kriterijima. Osim Vrapča, sve ostale ustanove imaju i jednokrevetne sobe i to Rab deset, Ugljan osam, a Popovača šest. Kriteriji za smještaj u jednokrevetne sobe vezani su uz želje pacijenata, ali isto tako vodi se računa o medicinskim i sigurnosnim razlozima.

Prema prikupljenim podatcima iz općeg upitnika za ravnatelje, sve četiri psihijatrijske ustanove imaju visoke higijenske standarde. Tako su svim pacijentima dostupne higijenske potrepštine (sapun, toaletni papir itd.), topla voda, sanitarni čvor, mogu se kupati ili tuširati svakodnevno, krevetnina se mijenja po potrebi, najkasnije svakih sedam dana. Spremačice ili vanjska tvrtka brinu o čistoći prostorija u kojima borave i rade pacijenti. Na Rabu i u Popovači uz spremačice u čišćenje prostorija

28 Eaton, N. R. i dr.: An Invariant Dimensional Liability Model of Gender Differences in Mental Disorder Prevalence: Evidence From a National Sample, Journal of Abnormal Psychology, vol. 121, br. 1, 2012., str. 282.-283.

29 Pravilnik o listama psihijatrijskih ustanova koje ispunjavaju uvjete za smještaj i liječenje djece odvojeno od punoljetnih osoba, NN 76/14. Psihijatrijske ustanove koje ispunjavaju uvjete za smještaj i liječenje djece odvojeno od punoljetnih osoba su: Psihijatrijska bolnica za djecu i mladež Zagreb, Klinički bolnički centar Zagreb, Klinički bolnički centar Rijeka i Klinički bolnički centar Osijek.

30 Čl. 41., st. 1. Pravilnika o minimalnim uvjetima u pogledu prostora, radnika i medicinskotehničke opreme za obavljanje zdravstvene djelatnosti, NN 61/11., 128/12., 124/15., 8/16. 
uključeni su i sami pacijenti.

Visoki standardi vezani su i uz prehranu pacijenata. U svim psihijatrijskim ustanovama u pravilu imaju tri do pet obroka, s time da su za posebne skupine pacijenata (dijabetičari, srčani bolesnici, vegetarijanci itd.) predviđeni odgovarajući jelovnici.

Najvažnija pitanja u upitnicima bila su vezana uz ostvarivanje prava pacijenata koja su izričito propisana ZZODS-om, a odgovori su gotovo istovjetni u svim psihijatrijskim ustanovama. Tako proizlazi da su u svim ustanovama pacijenti upoznati sa svojim pravima već kod prijema u psihijatrijsku ustanovu, najčešće usmeno, ali i pismeno istaknutim odredbama na oglasnim pločama, a i primjerak ZZODS-a stalno im je dostupan. Nadalje, pacijenti mogu konzultirati odvjetnika kada smatraju da je to potrebno, a isto tako i obratiti se ravnatelju ustanove (ili drugom nadležnom predstavniku) za podnošenje zahtjeva ili pritužbe. Pacijenti, također mogu svakodnevno primati posjete. Za svoj rad na radno-terapijskim poslovima primaju nagradu (uglavnom novčanu). U svim psihijatrijskim ustanovama podupire se suodlučivanje pacijenata i traži se njihov pristanak na predloženu terapiju, kao i pristanak za njihovo uključivanje u biomedicinska istraživanja. Razlike među psihijatrijskim ustanovama uočavaju se u korištenju komunikacijskih medija. Tako na Rabu pacijenti i u svojim sobama i u zajedničkim prostorijama mogu koristiti mobitel, radio prijemnik, televizor, internet, novine i knjige. U Vrapču također mogu koristiti sve navedene medije osim interneta. Na Ugljanu se internet ne može koristiti, televizor se koristi samo u zajedničkoj prostoriji, a svi drugi mediji mogu se koristiti u sobama pacijenata i zajedničkim prostorijama. U Popovači je u potpunosti isključeno korištenje interneta i novina, knjige se mogu koristiti u zajedničkim prostorijama, a ostali mediji u sobama i zajedničkim prostorijama.

U svim psihijatrijskim ustanovama provode se brojni različiti tretmani i aktivnosti: individualni i grupni tretmani, program učenja socijalnih vještina, sportske aktivnosti, edukacije, radno okupacijske aktivnosti, programi protiv ovisnosti.

U svim psihijatrijskim ustanovama provode se i mjere prisile. Uglavnom je riječ o fizičkom sputavanju, s time da se u Popovači i Vrapču primjenjuje i izdvajanje i to u Popovači u zasebne jednokrevetne sobe, a u Vrapču u posebnu prostoriju za izdvajanje (tzv. gumirana soba).

Tablica 2. Kadrovski kapaciteti zaposlenoga medicinskog te drugoga stručnog i administrativnog osoblja

\begin{tabular}{|l|c|c|c|c|c|c|}
\hline $\begin{array}{c}\text { Psihijatrijska } \\
\text { ustanova }\end{array}$ & $\begin{array}{c}\text { Ukupan broj } \\
\text { zaposlenih }\end{array}$ & Psihijatri & $\begin{array}{c}\text { Drugi } \\
\text { liječnici }\end{array}$ & $\begin{array}{c}\text { Medicinske } \\
\text { sestre }\end{array}$ & $\begin{array}{c}\text { Medicinski } \\
\text { tehničari }\end{array}$ & $\begin{array}{c}\text { Drugo stručno i } \\
\text { administrativno } \\
\text { osoblje }\end{array}$ \\
\hline Popovača & 539 & 33 & 24 & 183 & 94 & 205 \\
\hline Rab & 242 & 11 & 18 & 54 & 40 & 119 \\
\hline Ugljan & 251 & 12 & 6 & 115 & 32 & 86 \\
\hline Vrapče & 716 & 60 & 19 & 334 & 27 & 276 \\
\hline
\end{tabular}

Ukupan broj zaposlenih u istraživanim psihijatrijskim ustanovama prati veličinu 
smještajnih kapaciteta samih ustanova. Tako, očekivano, najviše zaposlenih ima Vrapče, slijedi Popovača, te Ugljan i Rab, kod kojih se primjenom istog kriterija raspoloživih mjesta, uočava nedostatak zaposlenih i to osobito psihijatara. Ovaj podatak treba dovesti u vezu s fluktuacijom zaposlenih u sve četiri ustanove. Tako je iz Vrapča u posljednjih godinu dana otišlo iz različitih razloga (odlazak u mirovinu, otkaz, osobni otkaz, sporazumni otkaz, smrt) ukupno 33 radnika, ali se i zaposlilo novih 38. U Popovači je u istom razdoblju zaposleno novih 30 zaposlenika, što je jednako broju onih koji su napustili ustanovu. Na Rabu je zaposleno novih 30, a ustanovu su napustile 22 osobe. Najteža je situacija na Ugljanu, gdje je iz ustanove otišlo 18, a zaposlilo se tek 11 osoba. Iz navedenih brojčanih pokazatelja, posebno kada se broj zaposlenih psihijatara dovede u odnos s brojem smještenih pacijenata u svakoj od istraživanih ustanova, jasno proizlazi neispunjavanje minimalnih standarda propisanih Pravilnikom o minimalnim uvjetima u pogledu prostora, radnika i medicinsko-tehničke opreme za obavljanje zdravstvene djelatnosti. ${ }^{31}$ Stoga ne iznenađuju upozorenja ravnatelja o lošoj kadrovskoj ekipiranosti unutar njihovih ustanova. ${ }^{32}$

\subsection{Rezultati i analiza upitnika za pacijente}

U istraživanju o uvjetima boravka, liječenja i poštovanju prava osoba s duševnim smetnjama, u istraživanim psihijatrijskim ustanovama sudjelovalo je ukupno osamdeset pacijenata. Najveći broj pacijenata nalazio se na liječenju u Popovači (31,3\%), potom u Vrapču (25\%) te Ugljanu (22,5\%) i Rabu (21,2 \%). Mali uzorak ispitanika bio je i očekivan jer se u anketiranje moglo uključiti samo one pacijente koji su u vrijeme provođenja ankete bili sposobni sudjelovati u istraživanju i tomu su se dobrovoljno odazvali. Reprezentativnost uzorka osigurana je činjenicom da su istraživački uzorak činili pacijenti smješteni na različitim psihijatrijskim odjelima uključujući i forenzički odjel.

U istraživanju su većinom sudjelovali muški pacijenti (70 \%) što dobro odražava omjer ukupnoga broja pacijenata i pacijentica u sve četiri psihijatrijske bolnice. Analiza kronološke dobi ispitanika pokazuje da $u$ istraživanju dominiraju osobe srednje životne dobi. Tako 87,5\% ispitanika pripadaju starijim od 30, a mlađim od 65 godina starosti. Nakon ove dobne kategorije slijede 7,5 \% osoba od 18 do 30 godina. Dvoje ispitanika nije navelo podatak o svojoj dobi. Prema dobivenim podatcima $u$ uzorku su najmanje zastupljeni pacijenti stariji od 65 godina $(2,5 \%)$ što je određeno odstupanje od podataka o dobi svih pacijenata na dan provođenja istraživanja koje su dostavili ravnatelji psihijatrijskih ustanova. Za pretpostaviti je da je mali broj gerijatrijskih pacijenata uključenih u anketiranje rezultat izostanka njihova interesa ili sposobnosti za sudjelovanjem.

31 Čl. 45., toč. 7. Pravilnika o minimalnim uvjetima u pogledu prostora, radnika i medicinskotehničke opreme za obavljanje zdravstvene djelatnosti, op. cit.

32 Na teške radne uvjete, posebice medicinskih sestara, upozorili su u svojim komentarima i pacijenti. Njihovo je mišljenje kako ,... rad s psihički onesposobljenim osobama iziskuje dosta snage, psihičke i fizičke“ i kako „uvjeti u kojima (medicinske sestre) rade definitivno nisu humani“, pa im je potrebno osigurati „veće plaće“. 
Grafikon 1. Zanimanje ispitanika

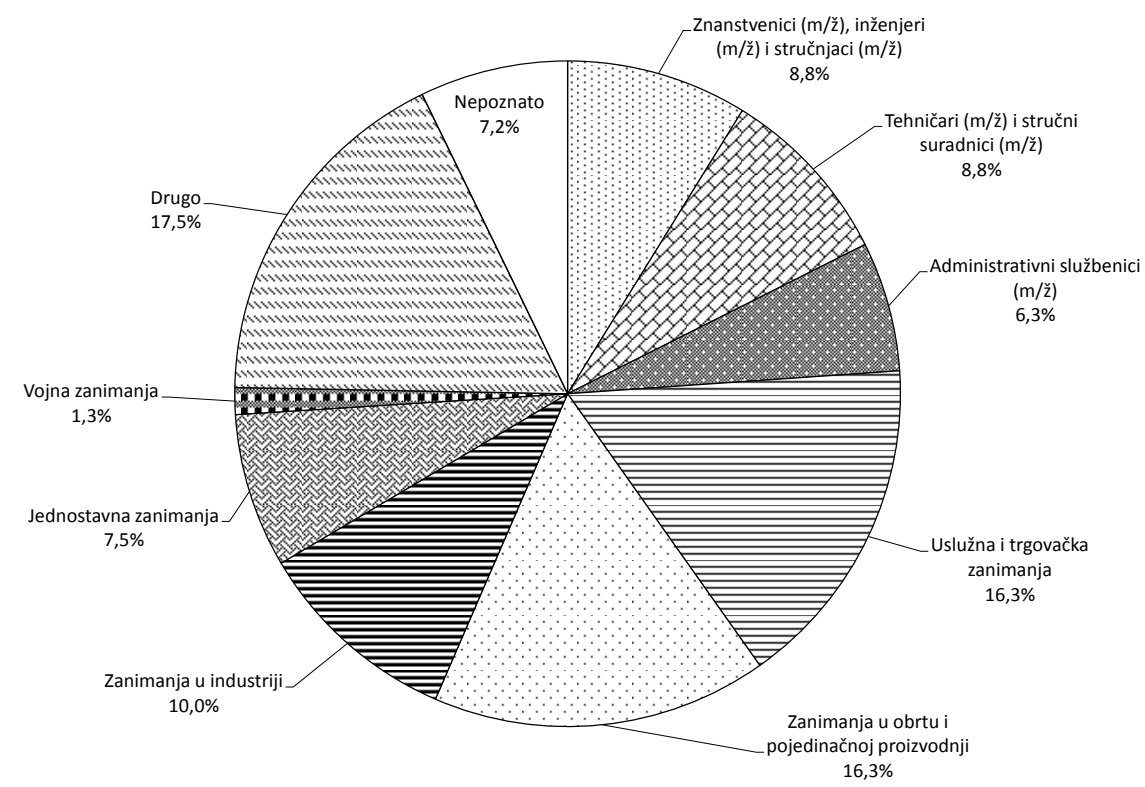

Pacijenti koji su sudjelovali u istraživanju različitih su zanimanja. Podatci o pozivu ispitanika govore da se velik broj njih bavio obrtničkim poslom i poslom u pojedinačnoj proizvodnji (16,3\%). Pacijenti iz istraživanja po zanimanju su vodoinstalateri, pismoslikari, zidari-tesari, tekstilni radnici, krojači, elektromehaničari, automehaničari, varioci, metalo-glodači i monteri strojeva. Jednaki postotak ispitanika radio je i u uslužnim i trgovačkim zanimanjima, a najveći broj kao kuhari i konobari (6 od 13 ispitanika). Među ispitanicima su i oni koji su imali vrlo zahtjevna radna mjesta (lektori, profesori, diplomirani ekonomisti, diplomirani geografi i slična znanstvena i stručna zanimanja), ali i oni koji su raspoređeni na jednostavne poslove (radnici i spremačice). Veliki broj ispitanika obavljao je tehničke i stručne suradničke poslove. Među 8,8 \% ispitanika našli su se tako strojarski tehničari, tehničari brodostrojarstva, elektrotehničari i laboratorijski tehničari. U uzorku su bili i administrativni službenici (administrativni referenti, knjigovođe, administrativno osoblje u turizmu i prometu) te jedna osoba s vojnim zanimanjem. Podatke o vlastitom zanimanju nije otkrilo šest ispitanika.

Iz grafičkoga prikaza proizlazi kako je najveći broj pacijenata ponudio odgovore o svom zanimanju koji su uvršteni u kategoriju „drugo“. Naime, pri analizi odgovora o profesiji ispitanika korištena je skala zanimanja iz Nacionalne klasifikacije zanimanja, ${ }^{33}$ no, neki od pacijenata u odgovoru su naveli podatak da su ,umirovljenici“, odnosno ,invalidna mirovina/penzija“ koji se nije mogao podvesti pod klasifikaciju. Odgovori ne iznenađuju ako se uzme u obzir činjenica, da su duševne smetnje odmah nakon oštećenja lokomotornog sustava drugi po redu uzrok invaliditeta u Republici Hrvatskoj. Prema podatcima iz Hrvatskoga registra o osobama s invaliditetom za 
2017. godinu, duševne smetnje dovele su do invaliditeta $25,3 \%$ upisanih korisnika. ${ }^{34}$ Samo deset godina unazad, duševne smetnje bile su na četvrtom mjestu po učestalosti uzroka invaliditeta ( $16 \%$ upisnika). ${ }^{35}$ Moguće je da se ovaj negativan trend odrazio i na odgovore ispitanika i nije isključeno da će se nastaviti i u budućnosti. Naime, nedavna istraživanja pokazala su da su neuropsihijatrijski poremećaji drugi vodeći uzrok invaliditeta u Europi. ${ }^{36}$ Rezultati provedenog upitnika ukazali su na još jednu zabrinjavajuću činjenicu. U kategoriju „drugo“ uvršteni su i odgovori ispitanika koji su naveli kao zanimanje podatak ,student", „,maturant jezične gimnazije“ i ,maturant gimnazije“. Uočeni podatci daju naslutiti kako nije isključeno da Hrvatska dijeli fenomen porasta duševnih smetnji u srednjoškolskoj i studentskoj populaciji zajedno s drugim razvijenim zemljama. ${ }^{37}$ Troje ispitanika, umjesto odgovora o zanimanju, navelo je podatak o postignutoj stručnoj spremi. Kako stručna sprema ne koincidira s klasifikacijom zanimanja i ovi su odgovori uvršteni u kategoriju „drugo“.

Tablica 3. Obiteljski status ispitanika

\begin{tabular}{|l|c|c|}
\hline & Br. ispitanika & $\mathbf{\%}$ \\
\hline Bez partnera $(\mathrm{m} / \check{\mathbf{z}})$ & 38 & $47,4 \%$ \\
\hline U izvanbračnoj zajednici & 5 & $6,3 \%$ \\
\hline U braku & 20 & $25,0 \%$ \\
\hline Rastavljen $(\mathrm{m} / \check{\mathrm{z}})$ & 10 & $12,5 \%$ \\
\hline Udovac $(\mathrm{m} / \check{\mathbf{z}})$ & 5 & $6,3 \%$ \\
\hline Nepoznato & 2 & $2,5 \%$ \\
\hline
\end{tabular}

Podatci o obiteljskom statusu ispitanika pokazuju da je gotovo polovica njih bila bez partnera ili partnerice u trenutku provođenja istraživanja (47,4 \%). Ako se ovom broju pridodaju i podatci o rastavljenim pacijentima (12,5\%) i udovcima $(6,3$ $\%$ ), proizlazi da je većinski udio ispitanika lišen bračno-partnerskih veza. Upadljiv udio samaca u skladu je s do sada provedenim istraživanjima, prema kojima znatan

34 Hrvatski zavod za javno zdravstvo: Izvješće o osobama s invaliditetom u Republici Hrvatskoj, Zagreb, 2017., str. 7.

35 Hrvatski zavod za javno zdravstvo: Izvješće o osobama s invaliditetom u Republici Hrvatskoj, Zagreb, 2007., str. 37.

36 Primjerice, $44 \%$ korisnika mirovinskih i socijalnih naknada i povlastica u Danskoj primaju novčanu pomoć od države na temelju invaliditeta nastalog zbog duševne smetnje. Gotovo identičan podatak zabilježen je u Finskoj (43\% korisnika), dok je situacija nešto povoljnija u Škotskoj (37 \% korisnika) i Moldaviji (25 \% korisnika). World Health Organization, Regional Committee for Europe: The European Mental Health Action Plan, Kopenhagen, 2013., str. 16.

37 U svom izvještaju za 2016. godinu, Centar za sveučilišno duševno zdravlje naveo je podatak da je u SAD-u zabilježen dramatičan porast korisnika sveučilišnih centara za savjetovanje studenata zbog duševne smetnje. (The Center for Collegiate Mental Health: 2016 Annual Report, Penn State University, University Park, 2017., str. 1.) Poučan prikaz statističkih podataka o učestalosti duševnih smetnji kod srednjoškolskih učenika daje Roberts, N., Stuart, H. i Lam, M.: High School Mental Health Survey: Assessment of a Mental Health Screen, La Revue canadienne de psychiatrie, vol. 53, br. 5, 2008., str. 314.-322. 
broj osoba s duševnim smetnjama rijetko uspije sklopiti brak, civilno partnerstvo ili osnovati izvanbračnu zajednicu. ${ }^{38}$ Razlozi su mnogobrojni i kompleksni, no stigmatizacija i strah od duševne smetnje potencijalnih partnera, otežan pronalazak zaposlenja i slabiji socioekonomski status osoba s psihičkom smetnjom zasigurno spadaju u uži krug negativnih faktora. Za razliku od većine drugih oboljenja, duševna smetnja je veliko opterećenje za obiteljski život i veze, pa stoga ne čudi podatak da se mali broj partnerskih zajednica uspije očuvati i prebroditi iskušenja koja u partnerske odnose donosi duševna patnja oboljeloga člana obitelji. ${ }^{39}$

Grafikon 2. Pravna osnova smještaja ispitanika u psihijatrijsku ustanovu

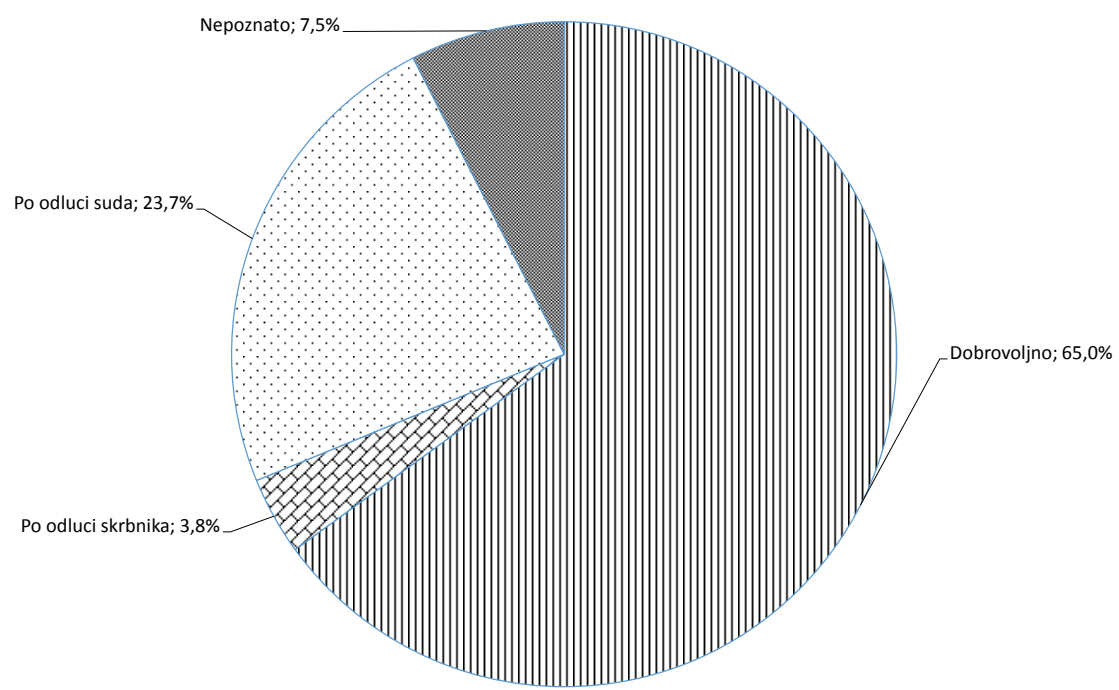

$\mathrm{U}$ istraživačkom uzorku najveći broj ispitanika smješten je na liječenje $u$ psihijatrijsku ustanovu na temelju njihova dobrovoljnog pristanka (njih pedeset $\mathrm{i}$ dvoje, odnosno $65 \%$ ). Dobiveni podaci u skladu su s općim podatcima o pravnim osnovama smještaja svih pacijenata u sve četiri psihijatrijske bolnice, prema kojima najveću kategoriju čine upravo dobrovoljno smješteni pacijenti. Prisilno smješteni forenzički pacijenti participiraju u uzorku s $23,7 \%$. Za samo tri ispitanika pristanak na smještaj u psihijatrijsku ustanovu dali su skrbnici. Šestoro pacijenata nije se izjasnilo o pravnim osnovama svoga smještaja. Dobiveni rezultati potvrđuju tezu kako je dobrovoljni smještaj primarna vrsta smještaja u psihijatrijskom sustavu, dok su smještaj bez pristanka i prisilni smještaj iznimne situacije.

38 Mahmoud, A. S. i dr.: Relationship between Social Support and the Quality of Life among Psychiatric Patients, Journal of Psychiatry and Psychiatric Disorders, vol. 1, br. 2, 2017., str. 64.

39 Kessler, R. C. i dr.: The Social Consequences of Psychiatric Disorders, III: Probability of Marital Stability, American Journal of Psychiatry, vol. 155, br. 8, 1998., str. 1092.-1096. 
Tablica 4. Trajanje hospitalizacije

\begin{tabular}{|l|c|c|}
\hline & Br. ispitanika & $\mathbf{\%}$ \\
\hline Do 30 dana & 13 & $16,2 \%$ \\
\hline Od 30 dana do 3 mjeseca & 23 & $28,8 \%$ \\
\hline Od 3 do 6 mjeseci & 14 & $17,4 \%$ \\
\hline Od 6 mjeseci do 1 godine & 2 & $2,5 \%$ \\
\hline Od 1 do 5 godina & 8 & $10 \%$ \\
\hline O 5 do 10 godina & 5 & $6,3 \%$ \\
\hline Od 10 do 15 godina & 4 & $5 \%$ \\
\hline Od 15 do 17 godina & 3 & $3,8 \%$ \\
\hline Neodgovarajući podaci & 7 & $8,7 \%$ \\
\hline Nepoznato & 1 & $1,3 \%$ \\
\hline
\end{tabular}

Iz tablice 4 proizlazi podatak da je u vrijeme provođenja istraživanja više od polovice ispitanika (točnije 62,4 \%) provelo na liječenju u psihijatrijskoj ustanovi manje od šest mjeseci. Štoviše, u ovoj skupini, kao i u ukupnom uzorku, najveći broj pacijenata nalazio se u bolnici više od mjesec dana, a manje od tri mjeseca. Relativno kratki boravci mogu biti rezultat prevladavajućih dobrovoljnih smještaja $\mathrm{u}$ istraživačkom uzorku. Ovime se ujedno i potvrđuje stav da dobrovoljno liječenje i suradnja liječnika i pacijenta dovodi do uspješnijih terapijskih rezultata u odnosu na prisilni smještaj i smještaj bez pristanka, ${ }^{40}$ što u konačnici smanjuje dužinu boravka pacijenata u ustanovama.

Iako trajanje hospitalizacije u navedenim kategorijama nije zabrinjavajuće, nužno je istaknuti podatak da je čak jedna četvrtina ispitanika smještena u psihijatrijsku ustanovu na vrijeme duže od jedne godine. Najduži boravak na liječenju zabilježen je kod dvojice ispitanika koji su se u psihijatrijskoj bolnici nalazili petnaest godina, odnosno kod ispitanika koji je na dan istraživanja u statusu pacijenta proveo šesnaest godina, jedanaest mjeseci i dvadeset i šest dana. Iznimno duge hospitalizacije dovode u sumnju uspješnost psihijatrijskog liječenja i potvrđuju bojazan da ideju o deinstitucionalizaciji u psihijatriji neće biti nimalo lako provesti u praksi. Pored toga prolongiranje smještaja u psihijatrijskim bolnicama negativno utječe i na održavanje socijalnih veza pacijenata s obitelji, prijateljima, kolegama, a sve to opet može umanjiti izglede za postizanje rehabilitacije. Isto tako, godinama dugi boravci u psihijatrijskim ustanovama opravdano dovode u pitanje svrhu njihova boravka u njima. Naime, ako smještaj pacijenata može trajati u bolnici i više od jednoga desetljeća, nije li tada primarna svrha hospitalizacije izdvajanje osobe s duševnim smetnjama iz društva zbog njezine potencijalne opasnosti? U tom kontekstu podatci o priznavanju prava ispitanika iz ZZODS-a tijekom njihova institucionalnog liječenja dobivaju iznimno značenje.

40 Grozdanić, V. (ur.), op. cit., str. 111. 
Tablica 5. Pravo na dostojanstvo i njegova zaštita

\begin{tabular}{|l|c|c|c|c|c|}
\hline & Ne znam & Nikad & Rijetko & Često & Uvijek \\
\hline $\begin{array}{l}\text { U ovoj ustanovi osjećam se sigurno i } \\
\text { zaštićeno. }\end{array}$ & $3,8 \%$ & $2,5 \%$ & $1,2 \%$ & $17,5 \%$ & $75 \%$ \\
\hline $\begin{array}{l}\text { U ovoj ustanovi poštuje se i štiti moje } \\
\text { dostojanstvo, slobode i prava. }\end{array}$ & $1,2 \%$ & $1,2 \%$ & $2,5 \%$ & $21,3 \%$ & $73,8 \%$ \\
\hline $\begin{array}{l}\text { U ovoj ustanovi prema meni se } \\
\text { jednako postupa kao i prema drugim } \\
\text { pacijentima. }\end{array}$ & $1,2 \%$ & $3,8 \%$ & $2,5 \%$ & $5 \%$ & $87,5 \%$ \\
\hline $\begin{array}{l}\text { Bolničko osoblje zaštitit će me od } \\
\text { ponižavanja i nasilničkog ponašanja } \\
\text { drugih osoba u ovoj ustanovi. }\end{array}$ & $1,2 \%$ & $1,2 \%$ & $1,2 \%$ & $20 \%$ & $76,4 \%$ \\
\hline
\end{tabular}

Velika većina ispitanika (njih šezdeset) izjavila je da se u psihijatrijskoj ustanovi u kojoj se nalaze uvijek osjećaju sigurno i zaštićeno. Osjećaj sigurnosti često je prisutan kod četrnaest $(17,5 \%)$ ispitanika, a rijetko kod jednog $(1,2 \%)$ odnosno nikada kod dva $(2,5 \%)$ ispitanika. Neki od ispitanika nisu dali odgovor o tomu kako se osjećaju tijekom hospitalizacije $(3,8 \%)$. Visok postotak zadovoljstva ispitanika u odnosu na sigurnost i zaštićenost odrazio se i na njihove ostale odgovore iz ove skupine pitanja.

Navedenu pretpostavku već potvrđuju odgovori na naredno pitanje. O tomu da se u ustanovi uvijek poštuje i štiti dostojanstvo, slobode i prava ispitanika izjasnilo se njih 73,8 \%. Sedamnaest ispitanika (21,3\%) zaokružilo je odgovor o čestom poštivanju i zaštiti jednog od temeljnih načela ZZODS-a. Odgovore o rijetkom poštovanju i zaštiti njihovog dostojanstva ponudila su samo dva ispitanika $(2,5 \%)$, odnosno o njihovu potpunom izostanku jedan ispitanik (1,2\%).

Zabrana diskriminacije, odnosno nejednakoga postupanja, jedna je od temeljnih ustavnih kategorija čije je poštovanje ključno kada se radi o ranjivim društvenim skupinama. Diskriminaciju nikako ne bi smjeli osjećati pacijenti u psihijatrijskim ustanovama koji se inače nalaze u nezavidnom položaju koji je najčešće obilježen ovisnošću, bespomoćnošću i strahom. U tom kontekstu, ohrabruje podatak da je čak $87,5 \%$ pacijenata odgovorilo da medicinsko osoblje nikada ne razlikuje njih i druge pacijente.

Dobiveni odgovori u skladu su s odgovorima na pitanje hoće li bolničko osoblje zaštititi ispitanike od ponižavanja i nasilničkoga ponašanja drugih osoba u psihijatrijskoj ustanovi. Velika većina ispitanika ocjenjuje da je bolničko osoblje uvijek (76,4 \%), odnosno često $(20 \%)$ spremno zaštititi ih od negativnih nasrtaja drugih. O potpunom izostanku odnosno o rijetkoj zaštiti izjasnio se samo jedan ispitanik. Opciju ,ne znam“ zaokružila je jedna osoba (1,2 \%). Iz dobivenih podataka može se zaključiti kako je procjena pacijenata postupa li bolničko osoblje u skladu s poštovanjem njihovoga dostojanstva usko vezana uz procjenu o spremnosti osoblja da se pacijente obrani od napada na njihovo dostojanstvo. 
Tablica 6. Pravo na informiranost

\begin{tabular}{|l|c|c|c|c|c|}
\hline & Ne znam & Nikad & Rijetko & Često & Uvijek \\
\hline $\begin{array}{l}\text { Tijekom prijema upoznat sam sa } \\
\text { svojim pravima iz ZZODS-a. }\end{array}$ & $1,2 \%$ & $12,5 \%$ & $2,5 \%$ & $21,3 \%$ & $62,5 \%$ \\
\hline $\begin{array}{l}\text { Upoznat sam s razlozima i ciljevima } \\
\text { moga smještaja u psihijatrijsku } \\
\text { ustanovu. }\end{array}$ & $2,5 \%$ & $3,8 \%$ & $5 \%$ & $10 \%$ & $78,7 \%$ \\
\hline $\begin{array}{l}\text { Kada to zatražim, daje mi se uvid u } \\
\text { moju medicinsku dokumentaciju. }\end{array}$ & $15 \%$ & $6,3 \%$ & $7,5 \%$ & $15 \%$ & $56,2 \%$ \\
\hline
\end{tabular}

Prema dobivenim podatcima, velika većina ispitanika upoznata je sa svojim pravima propisanim u ZZODS-u. Njih 62,5 \% izjasnilo se da je tomu tako kod svakoga prijema u psihijatrijsku ustanovu, dok $21,3 \%$ naglašava da ih se s pravima upoznaje često. Iako u svojim odgovorima iz osnovnih upitnika ravnatelji Vrapča, Popovače, Raba i Ugljana navode kako pacijenti dobivaju saznanja o pravima iz ZZODS-a već kod samog prijema i kako im je primjerak ovog zakona stalno dostupan, deset ispitanika $(12,5 \%)$ tvrdi da nikada nije bilo upoznato sa svojim pravima, odnosno njih dvoje $(2,5 \%)$ da je takvo što rijetkost. Uočene nepodudarnosti u odgovorima ne treba ignorirati, budući da je poznavanje zakonom zagarantiranih prava nužna pretpostavka za pokretanje mehanizama zaštite u slučaju njihovog kršenja.

Manja odstupanja vidljiva su u odgovorima na pitanje jesu li ispitanici upoznati s razlozima i ciljevima njihovog smještaja, jer je 78,7 \% njih dalo pozitivne odgovore.

Ovakvi rezultati pokazuju da su pacijenti više informirani o razlozima i cilju osobnoga liječenja nego o posebnim pravima koja im pripadaju kao psihijatrijskim pacijentima. Jedan od razloga nedovoljne informiranosti o pravima može biti povezan s činjenicom da psihijatri kao stručnjaci iz područja medicine pacijentima radije objašnjavaju razloge njihova liječenja negoli pružaju informacije o pravima koja su u biti jedan pravni konstrukt svojstven više pravničkoj, no liječničkoj profesiji. Isto tako nije isključeno da sami psihijatri još uvijek nisu dovoljno upoznati sa svojom obvezom da već pri prijemu pouče osobu s duševnim smetnjama o njenim pravima i načinima kako se ona mogu ostvariti. Ako je ova obveza psihijatra samo formalno provedena (primjerice isticanjem liste prava na oglasnim pločama obješenim u psihijatrijskim klinikama), pravo na informiranost o pravima psihijatrijskih pacijenata ne bi bilo ispunjeno i u tim bi okolnostima pacijenti mogli zaključiti kako ih nikada nitko nije poučio o njima. Budući da svaki pojedini pacijent ima pravo biti upoznat s pravima psihijatrijskih pacijenata (čl. 14., st. 1., toč. 1. ZZODS-a) i s ciljevima i razlozima vlastitoga smještaja (čl. 14., st. 1., toč. 2. ZZODS-a) i da su ta prava jednake zakonske snage, ne bi trebala postojati razlika u informiranosti. Naime, podbačaj psihijatrijskog osoblja u ostvarivanju bilo kojeg od tih prava povreda je ZZODS-a.

Pravo uvida pacijenata u medicinsku dokumentaciju preduvjet je njihove dobre informiranosti, a koja je opet nužna za donošenje ispravnih odluka o prihvaćanju ili odbijanju predloženih medicinskih postupaka. Stoga zabrinjava podatak da je samo $56,2 \%$ pacijenata u potpunosti ostvarilo ovo pravo. Ističe se i podatak da je čak 15 $\%$ ispitanika među ponuđenim odgovorima odabralo odgovor „ne znam“. Moguće je 
da se u ovoj kategoriji nalaze i odgovori pacijenata koji nisu niti upoznati sa svojim pravom da zatraže uvid u svoju medicinsku dokumentaciju ili znaju za to pravo, ali nikada za tim nisu imali potrebe. Isto je tako moguće da su takav zahtjev postavili, ali na njega uopće nisu dobili odgovor ili je odgovor bio sročen uz uporabu medicinskih termina i u konačnici za samoga pacijenta nedovoljno razumljiv. ${ }^{41}$

Podatci iz tablice 6. stoga upozoravaju kako na najveće prepreke u ostvarivanju svojih prava ispitanici nailaze upravo kod prava na informiranost. Određena pasivnost bolničkog osoblja može biti uzrokovana uvriježenim stajalištem kako postavljanje medicinskih dijagnoza i provođenje terapijskih tretmana treba ostaviti u rukama stručnjaka. U kompleksnom odnosu psihijatra i pacijenta, pacijent je pasivna strana koja se s punim povjerenjem prepušta stručnim odlukama liječnika psihijatra koji je dužan te odluke donositi u skladu s najboljim interesom pacijenta. Ovakvo stajalište ukorijenjeno je u paternalističkom pristupu države prema psihijatrijskim pacijentima. Kao nositelj parens patriae ovlasti, država je dužna skrbiti o osobama s duševnim smetnjama jer one nisu u mogućnosti brinuti o vlastitim interesima. ${ }^{42}$ Paternalistički pristup teorijska je postavka medicinskoga modela prema kojem se psihijatrijski pacijenti po svojoj dijagnozi razlikuju od ostatka društva i zbog koje ih je potrebno uključiti u psihijatrijski tretman. ${ }^{43}$ Ovakav pretjerano zaštitnički pristup naklonjen etiketiranju i izdvajanju psihijatrijskih pacijenata iz zajednice podložan je sve snažnijoj stručnoj i znanstvenoj kritici te se sve više zagovara njegovo napuštanje. Umjesto medicinskoga modela predlaže se usvajanje socijalnoga modela, koji je usmjeren na društvenu inkluziju osoba s duševnim smetnjama i promicanje ideje deinstitucionalizacije. ${ }^{44}$ Minimalni standardi koji se moraju ostvariti kako bi se ozbiljno porazmislilo o rekonstrukciji psihijatrijskoga sustava u smjeru usvajanja elemenata socijalnoga modela upravo je priznavanje prava na informiranost osoba $\mathrm{s}$ duševnim smetnjama.

41 U znanstvenim i stručnim radovima može se pronaći kritika upućena „medicinskom žargonu“ kojim se liječnici služe kako bi pacijentima objasnili njihovo zdravstveno stanje i moguće metode liječenja. Medicinska frazeologija svojevrsno je oružje u rukama medicinara kojim medicina nastoji zadržati svoj dominirajući položaj u odnosu na pacijente i društvene institucije. Starr, P.: The Social Transformation of American Medicine, The Rise of Sovereign Profession and the Making of a Vast Industry, Basic Books, New York, 1982., str. 51.-52.

42 Kopel, D. B. i Cramer, C. E.: Reforming Mental Health Law to Protect Public Safety and Help the Severely Mentally Ill, Howard Law Journal, vol. 58, 2014., str. 761.

43 Counts, N.: Accommodating One Another: Law and the Social Model of Mental Health, Kansas Journal of Law \& Public Policy, vol. 25, br. 1, 2015., str. 6.

44 Za razliku do medicinskog modela, prema socijalnom modelu primaran fokus države ne smije biti na medicinskoj dijagnozi, već na mnogo širem kontekstu poimanja društva kao zajednice jednako vrijednih osoba koje nose svoje različitosti. Unutar socijalnog modela preispituju se postojeće prepreke u društvu i primjenjuju mjere za njihovo otklanjanje, kako bi osobe s duševnim smetnjama ostvarile svoje pune potencijale. Osim u teorijskim radovima, ovaj model promiče i Konvencija o pravima osoba s invaliditetom (NN-MU 6/07., 3/08., 5/08.), a kao korektiv medicinskog modela sve ga više zagovaraju i službena tijela UN-a (Human Rights Council, Report of the Special Rapporteur on the right of everyone to the enjoyment of the highest attainable standard of physical and mental health, A/HRC/35/21, 28. ožujka 2017.). 
Tablica 7. Pravo na suodlučivanje u medicinskom tretmanu

\begin{tabular}{|l|c|c|c|c|c|}
\hline & Ne znam & Nikad & Rijetko & Često & Uvijek \\
\hline $\begin{array}{l}\text { U ovoj ustanovi sudjelujem u } \\
\text { planiranju i provođenju svoga } \\
\text { liječenja. }\end{array}$ & $1,3 \%$ & $6,3 \%$ & $7,5 \%$ & $17,5 \%$ & $67,4 \%$ \\
\hline $\begin{array}{l}\text { U ovoj ustanovi prije provođenja } \\
\text { svakog medicinskog postupka } \\
\text { zatražen je moj pisani pristanak. }\end{array}$ & $6,3 \%$ & $18,8 \%$ & $10 \%$ & $7,5 \%$ & $57,4 \%$ \\
\hline $\begin{array}{l}\text { U ovoj ustanovi mogu slobodno } \\
\text { iznositi osobna uvjerenja i želje o } \\
\text { mom medicinskom tretmanu i ne } \\
\text { trebam se bojati da ću zbog njih biti } \\
\text { izložen neugodnostima. }\end{array}$ & $2,5 \%$ & $2,5 \%$ & $7,5 \%$ & $17,5 \%$ & $70 \%$ \\
\hline
\end{tabular}

Pravo na informiranost preduvjet je koji se mora ispuniti kako bi se ostvarilo pravo psihijatrijskih pacijenata da sudjeluju u planiranju i provođenju vlastitog liječenja. Analiza prikupljenih odgovora na prvo pitanje iz tablice 7. pokazuje da $67,4 \%$ pacijenata uvijek odnosno $17,5 \%$ često sudjeluje u planiranju i provođenju svoga liječenja. Ovaj rezultat o suodlučivanju u medicinskom tretmanu može biti pokazatelj za ocjenu kvalitete psihijatrijske skrbi u psihijatrijskim ustanovama, no ne i jedini i isključivi parametar. Naime, treba imati na umu da je spremnost i volja da se sudjeluje u planiranju i provođenju medicinskoga tretmana usko vezana uz osobne odabire svakoga ispitanika i može se razlikovati od osobe do osobe. ${ }^{45}$ Zbog toga je ključno ispitati pribavlja li se pisani pristanak ispitanika prije provođenja medicinskoga postupka kao objektivni parametar koji spada u temeljnu zakonsku obvezu psihijatrijskih stručnjaka.

Pribavljanje valjanog, informiranoga, pisanog pristanka osobe s duševnom smetnjom prije negoli što se nad njom provede neki medicinski postupak, temeljni je postulat u postupanju liječnika psihijatara u odnosu na njihove pacijente. Kako bi se pacijenti zaštitili od samovoljnoga liječenja, a psihijatri od neutemeljenih pritužbi pacijenata, svaki pristanak na medicinski postupak mora se pribaviti u pisanoj formi. U protivnome, dolazi do kršenja prava pacijenata. Prema podatcima iz tablice 7., to je zabilježeno u 18,8 \% slučajeva. O učestalom kršenju ovoga prava izjasnilo se 8 pacijenata $(10 \%)$ budući da se od njih rijetko zatražio pisani pristanak na medicinske postupke.

Dobiveni podatci pokazuju kako se ipak u nekim slučajevima ne podupire i ne provodi suodlučivanje pacijenata u osmišljavanju i primjeni vlastite terapije. Razlozi koji su doveli do nepodudaranja dijela odgovora pacijenata s odgovorima ravnatelja mogu biti različiti, pa tako nije isključeno da dio psihijatrijske struke vjeruje kako je sasvim dovoljno dobiti usmeni pristanak pacijenta na provođenje medicinskoga postupka. Inzistiranje na pismenoj formi pristanka može se smatrati nepotrebnim administriranjem i dodatnim opterećenjem u provođenju liječničkoga posla. Isto tako nije isključeno da je do kršenja prava pacijenata u više od jedne četvrtine

45 Potter, N.: The Virtue of Defiance and Psychiatric Engagement, Oxford University Press, Oxford, 2016., str. 4. 
slučajeva upravo došlo zbog nedovoljne informiranosti pacijenata i njihove ovisnosti o psihijatrima. Mogući uzroci mogu biti vezani i uz samu psihijatrijsku struku, primjerice uz propuste u edukaciji stručnjaka o informiranom pristanku i manjkavost mehanizama kontrole za njegovo valjano pribavljanje. ${ }^{46}$

O važnosti uključivanja prisilno hospitaliziranih pacijenata u prosudbu medicinskih tretmana govore mnogobrojne studije. ${ }^{47}$ Pravo na slobodno izražavanje vlastitoga mišljenja o medicinskim postupcima ključan je element za donošenje odluke o kvaliteti psihijatrijske skrbi. ${ }^{48}$ Stoga ohrabruje podatak da iako gotovo polovica pacijenata nema priliku pismeno izraziti svoje slaganje s predloženim medicinskim tretmanom, velika većina njih (56 ispitanika, odnosno 70 \%) može uvijek slobodno dati svoj sud o tretmanu, nakon što se započne s njegovim provođenjem. Pravo na vlastito izražavanje mišljenja bez bojazni od neugodnosti često je ostvareno kod 17,5 $\%$ ispitanika. Šest sudionika u istraživanju smatra da se rijetko nalaze u ovakvoj prilici dok borave u psihijatrijskoj ustanovi, dok dvoje nikada nije imalo ovo pravo. O istom se pitanju nije znalo izjasniti dvoje ispitanika.

Grafikon 3. U ovoj ustanovi liječničko osoblje brine o zaštiti i unaprjeđenju moga zdravlja i o mom osobnom razvoju i spremni su mi pomoći kada za to imam potrebu.

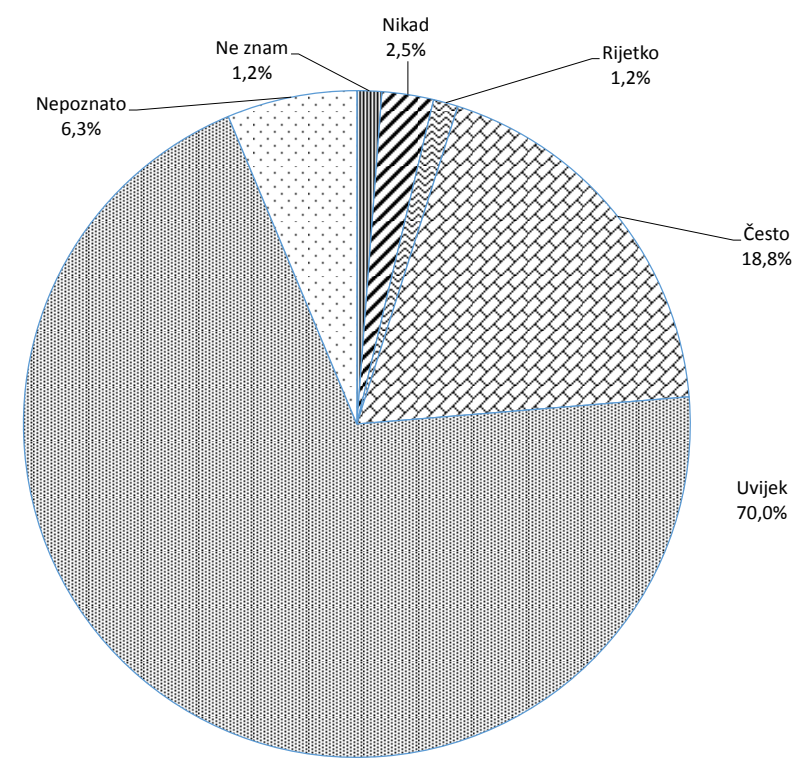

Podatci u grafikonu 3. pokazuju kako je izrazito velika većina ispitanika zadovoljna postupanjem liječničkog osoblja. Čak 78,8\% ispitanika iskazuje da

46 O problemima vezanim uz pribavljanje informiranog pristanka psihijatrijskih pacijenata vidi u: Goreta, M.: Errare humanum est, Najčešće pogreške u forenzičko-psihijatrijskoj praksi, Naklada Slap, Jastrebarsko, 2015., str. 126.-129.

47 Längle, G. i dr.: Indicators of Quality of In-Patient Psychiatric Treatment: The Patients' View, International Journal for Quality in Health Care, vol. 15, br. 3, 2003., str. 213.-214.

48 Schröder, A. i dr.: Patients' Perceptions of the Concept of the Quality of Care in the Psychiatric Setting: A Phenomenographic Study, Journal of Clinical Nursing, vol. 15, br. 1, 2006., str. 93. 
liječnici uvijek odnosno često brinu o zaštiti i unaprjeđenju njihova zdravlja i o njihovu osobnom razvoju. Osim samoinicijativne brige za pacijenta, liječničko osoblje je isto tako spremno pomoći pacijentima kada za to imaju potrebu. ${ }^{49}$ Samo dva ispitanika $(2,5 \%)$ nisu nikada primila ovakvu pomoć i brigu liječnika tijekom boravka u psihijatrijskoj ustanovi. Jedan pacijent izjasnio se da mu je pomoć i briga liječničkog osoblja rijetko pružena. Kao i u prethodnom pitanju, ponovilo se da pet ispitanika nije zaokružilo niti jedan od ponuđenih odgovora. Analiza ponuđenih odgovora možda najbolje prikazuje stav ispitanika o njihovu položaju u psihijatrijskoj ustanovi budući da se u postavljenom pitanju tražila u potpunosti subjektivna procjena ispitanika o postupanju liječničkog osoblja u odnosu na njih.

Tablica 8. Pravo na odgovarajuće uvjete smještaja

\begin{tabular}{|l|c|c|c|c|c|c|}
\hline & Ne znam & Nikad & Rijetko & Često & Uvijek & Nepoznato \\
\hline $\begin{array}{l}\text { U ovoj ustanovi uvjeti } \\
\text { smještaja odgovaraju mojim } \\
\text { potrebama. }\end{array}$ & $1,2 \%$ & $3,8 \%$ & $6,3 \%$ & $21,2 \%$ & $62,5 \%$ & $5 \%$ \\
\hline $\begin{array}{l}\text { U svojoj sobi imam dovoljno } \\
\text { prostora i ne osjećam se } \\
\text { skučeno. }\end{array}$ & $0 \%$ & $6,3 \%$ & $5 \%$ & $13,8 \%$ & $67,4 \%$ & $7,5 \%$ \\
\hline $\begin{array}{l}\text { U ovoj ustanovi mogu } \\
\text { slobodno koristiti moje } \\
\text { osobne predmete. }\end{array}$ & $0 \%$ & $3,8 \%$ & $7,5 \%$ & $11,2 \%$ & $71,2 \%$ & $6,3 \%$ \\
\hline $\begin{array}{l}\text { U ovoj ustanovi sanitarni } \\
\text { čvorovi su opskrbljeni toplom } \\
\text { vodom, sapunom i toalet } \\
\text { papirom. }\end{array}$ & $0 \%$ & $6,3 \%$ & $15 \%$ & $25 \%$ & $48,7 \%$ & $5 \%$ \\
\hline
\end{tabular}

Nešto manje zadovoljavajući odgovori zabilježeni su kod pitanja o kvaliteti smještaja u psihijatrijskim ustanovama. Tako pedeset ispitanika $(62,5 \%)$ smatra da uvjeti smještaja uvijek odgovaraju njihovim potrebama. Dvije trećine manje ispitanika $(21,2 \%)$ tvrdi da je smještaj često primjeren. Pet je ispitanika ocijenilo smještaj kao rijetko primjerenim njihovim potrebama odnosno tri ispitanika kako to nikada nije bio slučaj. Na postavljeno pitanje četiri ispitanika nisu odgovorila. ${ }^{50}$ Dobiveni rezultati ukazuju na postojanje propusta pri osiguranju adekvatnih okolišnih uvjeta u psihijatrijskim ustanovama i dio su jedne opće slike stanja u psihijatrijskom

49 Tako, npr. o spremnosti liječničkog osoblja da brinu ne samo o zdravlju pacijenata već im pruže i podršku i pomoć u životnim nedaćama govori komentar ispitanika koji je imao potrebu istaknuti „bolničko osoblje uvijek ima vremena za saslušanje mojih privatnih problema.“

50 Jedan od razloga koji je naveo ispitanike da ocijene kako uvjeti smještaja u ustanovi ne odgovaraju njihovim potrebama zasigurno leži u neadekvatnoj prehrani pacijenata. Tako, npr. neki ispitanici tvrde da je u psihijatrijskoj bolnici „hrana dosta loša“. Isto tako, pojedini se ispitanici žale na grupno ukidanje slobodnog popodnevnog izlaska svim pacijentima, kojima je prethodno odobreno to pravo, s time da za odluku o obustavi „ne znaju razlog“. Ispitanici su stalno zatvoreni na svojim odjelima jer nemaju ,popodnevni izlazak na friški zrak zimi niti ljeti“. 
bolničkom sustavu. ${ }^{51}$ Primjerice, u nekolicini izvještaja Pučka pravobraniteljica opetovano je upozoravala da na nekim odjelima psihijatrijskih ustanova i dalje postoje neprihvatljivi prostorni uvjeti. Unatoč pozitivnim pomacima, kao što je to planirano preseljenje pacijenata u novu zgradu Zavoda za forenzičku psihijatriju u Vrapču 2017. godine, nije isključeno da su životni uvjeti u nekim psihijatrijskim bolnicama dosegli ponižavajuće i nečovječno postupanje. ${ }^{52}$

Podatci prikupljeni provođenjem osnovnih upitnika za ravnatelje ukazali su na smještajnu podkapacitranost većine psihijatrijskih ustanova. Ukupan broj pacijenata manji je od broja raspoloživih postelja prema dopuštenim smještajnim kapacitetima ustanova osim u Ugljanu. Budući da u ovoj ustanovi broj pacijenata premašuje četiri bolesničke postelje, općenito gledano ne može se govoriti o prenapučenosti psihijatrijskih ustanova. Kako bi se ocijenilo odgovara li opća usklađenost sa smještajnim standardima na razini ustanove i smještaju na razini spavaonica, od pacijenata je zatraženo da ocijene adekvatnost prostora u bolničkim sobama. Tako se pedeset četiri pacijenata $(67,4 \%)$ izjasnilo kako u svojoj sobi uvijek imaju dovoljno prostora i kako se ne osjećaju skučeno. S raspoloživim prostorom često je zadovoljno 11 ispitanika (13,8 \%). Prostor u sobi kao rijetko dovoljnim i prostranim ocjenjuje 4 pacijenta (5\%). Petoro njih smatra kako u sobi nisu nikada imali dovoljno prostora i kako su se zbog toga osjećali skučeno. Šest pacijenata nije odgovorilo na postavljeno pitanje.

Analiza rezultata iz tablice 8. pokazuje kako ipak postoje problemi vezani uz prenapučenost soba. Osjećaj nedovoljno dostupnog prostora i skučenosti 11,3 $\%$ ispitanika upućuje na zaključak kako se u nekim slučajevima za svaki krevet $\mathrm{u}$ spavaonici nije uspjelo osigurati šest metara kvadratnih površine, što nalaže Pravilnik o minimalnim uvjetima u pogledu prostora, radnika i medicinsko-tehničke opreme za

51 Na navedeno ukazuje i zaključak ispitanice kako „s obzirom na stanje u zdravstvu općenito, svjesna sam da ne mogu biti ispunjene naše želje za boljim uvjetima odnosno kvalitetnijim smještajem u bolnicama."

$52 \mathrm{Na}$ temelju provedenog obilaska psihijatrijskih ustanova u Popovači, Ugljanu, Rabu, Vrapču i Lopači, Ured Pučke pravobraniteljice sastavio je izvješće u kojem je upozoreno na kršenje prava pacijenata na primjerene uvjete smještaja. Na nekim odjelima prostorije su u potpunosti bile neprimjerene za smještaj pacijenata, a zabilježeni su i drugi smještajni problemi zbog kojih su pacijentima ugrožena neka druga prava, primjerice pravo na privatnost, sloboda kretanja i zabrana ponižavajućeg postupanja. (Republika Hrvatska, Pučki pravobranitelj: Izvješće o ljudskim pravima osoba s duševnim smetnjama u psihijatrijskim ustanovama u okviru djelovanja Nacionalnog preventivnog mehanizma u 2014. godini, Zagreb, 2015., str. 8.) U Izvješću za 2015. godinu skrenuta je pozornost na neprihvatljivo stanje na Odjelu psihogerijatrije u Vrapču, u kojem uvjeti smještaja starijih i teško pokretnih pacijenata predstavljaju ponižavajuće uvijete. (Republika Hrvatska, Pučki pravobranitelj: Izvješće Pučke pravobraniteljice za 2015. godinu, Zagreb, 2016., str. 160.) U 2016. godini djelatnici Ureda Pučke pravobraniteljice posjetili su Kliniku za psihijatriju KBC-a Rijeka, Odjel za psihijatriju Opće bolnice Pula, Psihijatrijsku bolnicu za djecu i mladež i Odjel za dječju i adolescentnu psihijatriju KBC-a Osijek. Zbog utvrđenih smještajnih propusta, Ured Pučke pravobraniteljice izdao je 10 upozorenja i 20 preporuka te pozvao na žurnu adaptaciju postojećeg prostora i izgradnju novoga. (Republika Hrvatska, Pučki pravobranitelj: Izvješće Pučke pravobraniteljice za 2016. godinu, Zagreb, 2017., str. 185.-186.) 
obavljanje zdravstvene djelatnosti. ${ }^{53},{ }^{54}$ Rezultati provedenog istraživanja u skladu su s analizom smještaja u psihijatrijskim ustanovama u Vrapču, Popovači, Rabu, Ugljanu i Lopači, koje je 2014. godine proveo Ured Pučke pravobraniteljice. Zaključeno je kako je zbog prenapučenosti soba ugroženo pravo na privatnost pacijenata i zatraženo je hitno preuređenje prostora koje se, ako je suditi prema rezultatima ovog istraživanja, još uvijek nije ispunilo. ${ }^{55}$

Rezultati provedenog istraživanja pokazali su da je pravo određenog broja ispitanika na odgovarajući smještaj, osim zbog skučenog prostora u bolničkim sobama, opterećeno i nemogućnošću korištenja osobnih predmeta. Jedanaest ispitanika (11,3 \%) nikada nije moglo koristiti osobne stvari ili su ih koristili rijetko. S druge strane devet ispitanika $(11,2 \%)$ izjavilo je kako često mogu koristiti svoje predmete, dok ih pedeset i sedam $(71,2 \%)$ koristi uvijek. Pet ispitanika, odnosno $6,3 \%$ njih, nije odgovorilo na postavljeno pitanje.

Pravo na posjedovanje predmeta za osobnu uporabu jedno je od temeljnih prava osoba s duševnim smetnjama koje se liječe u psihijatrijskim ustanovama (čl. 14., st. 1., toč. 14. ZZODS-a), i kao svako drugo pravo proizašlo je iz prava na privatnost te je podložno odgovarajućim ograničenjima u skladu $s$ načelom razmjernosti. ${ }^{56}$ Takva ograničenja mogu trajati samo onoliko koliko je to potrebno da bi se ostvario zagarantirani legitimni cilj proklamiran u zakonu. ${ }^{57}$ Stoga apsolutne zabrane koje se primjenjuju tijekom cijeloga trajanja smještaja zabilježene u odgovoru „nikad“

53 Čl. 43., st. 7., toč. 3. Pravilnika o minimalnim uvjetima u pogledu prostora, radnika i medicinskotehničke opreme za obavljanje zdravstvene djelatnosti, op. cit.

54 Na prenapučenost bolničkih soba osvrnuli su se i ispitanici ističući kako borave u ,pretrpanim sobama“, odnosno kako je „previše pacijenata u sobama“. Jedan od problema je i izostanak sustavnoga smještaja pacijenata po odjelima. Pacijenti tako navode da u istoj sobi mogu boraviti pacijenti s različitim dijagnozama, a što za njih može biti dodatno, negativno opterećenje.

55 Republika Hrvatska, Pučki pravobranitelj: Izvješće o ljudskim pravima osoba s duševnim smetnjama u psihijatrijskim ustanovama u okviru djelovanja Nacionalnog preventivnog mehanizma u 2014. godini, op. cit., str. 8.-9.

56 Određena ograničenja prava psihijatrijskih pacijenata na posjedovanje osobnih predmeta, zabilježena su i u istraživanju grupe autora o kvaliteti smještaja u rezidencijalnim zajednicama za osobe s duševnim smetnjama u Italiji, koje su po svom režimu otvorenije strukture od psihijatrijskih ustanova uključenih u ovo istraživanje. U $68,3 \%$ slučajeva djelatnici rezidencijalnih centara pretraživali su osobne predmete korisnika, a u 18,2 \% vodili popis njihovih osobnih stvari. (Santone, G. i dr.: The Process of Care in Residential Facilities - A National Survey in Italy, Social Psychiatry \& Psychiatric Epidemiology, vol. 40, br. 7, 2005., str. 542.) Da pravo na posjedovanje osobnih predmeta može biti sporno i u Republici Hrvatskoj, pokazuje izvješće nevladinih organizacija iz 2011. godine, prema kojem je u svim psihijatrijskim ustanovama u kojima je izvršen nadzor uočen vrlo mali broj osobnih predmeta na vidljivim mjestima. Naime, ,... zidovi spavaćih soba su uglavnom bili goli i bez satova ili slika. Osim cigareta i ostalih toaletnih potrepština na noćnim stolićima, činilo se da osobe koje tamo žive imaju vrlo malo osobnih stvari.“ (Mental Disability Advocacy Center, Udruga Sjaj: Daleko od očiju, Ljudska prava u psihijatrijskim bolnicama i ustanovama socijalne skrbi u Hrvatskoj, Budimpešta, Zagreb, 2011., str. 67.)

57 Prema čl. 14., st. 4. ZZODS-a, pravo na posjedovanje predmeta za osobnu uporabu može se ograničiti jedino „... ako postoji opravdana sumnja da osoba s duševnim smetnjama nastoji pribaviti alkohol, drogu ili oružje, dogovara se o bijegu ili počinjenju težeg kaznenog djela ili bi korištenje tih prava moglo teško narušiti zdravlje ili sigurnost osobe.“ 
zasigurno nisu prihvatljive, ako nisu pravedan balans između prava na privatnost $\mathrm{i}$ prava države da provodi mjere zaštite sigurnosti i zdravlja građana.

Uvjeti smještaja u odnosu na sanitarne čvorove još je jedno pitanje na koje su pacijenti i ravnatelji psihijatrijskih ustanova ponudili različite odgovore. Prema tvrdnjama ravnatelja, svim su pacijentima dostupne higijenske potrepštine (sapun, toaletni papir itd.) i sanitarni čvorovi, no da je tomu uvijek tako izjavilo je samo 39 ispitanika (48,7\%). O čestoj opskrbljenosti sanitarnih čvorova toplom vodom, sapunom i toaletnim papirom izjasnilo se 20 ispitanika (25\%), dok $12(15 \%)$ smatra da je to rijetkost. Devet ili 6,3\% pacijenata uključenih u istraživanje nikada nije imalo odgovarajuće higijenske standarde sanitarnih jedinica tijekom boravka u psihijatrijskoj ustanovi..$^{58}$ Iako u hrvatskom javnom prostoru trenutno vlada retorika ,pretjerano skupog“ zdravstvenoga sustava, a izvještavanje medija o teškim smještajnim uvjetima pacijenata na bolničkom liječenju gotovo prolazi nezapaženo jer nije nikakva novina, ne smije se smetnuti s uma da je svaki neuspjeh u zadovoljavanju standarda bolničke higijene ujedno i podbačaj u stvaranju pozitivnoga terapijskog okruženja. Boravak u neodgovarajućim smještajnim uvjetima psihijatrijskih pacijenata može biti vanjski stresor koji, osim što umanjuje izglede za uspješno liječenje, može dovesti i do ponižavajućeg postupanja, a time i odgovornosti bolničkog osoblja. ${ }^{59}$

Tablica 9. Pravo na kontakte i komunikaciju

\begin{tabular}{|l|c|c|c|c|c|c|}
\hline & Ne znam & Nikad & Rijetko & Čsto & Uvijek & Nepoznato \\
\hline $\begin{array}{l}\text { U ovoj ustanovi svakoga } \\
\text { tjedna redovito primam } \\
\text { posijete. }\end{array}$ & $6,3 \%$ & $27,5 \%$ & $18,7 \%$ & $13,7 \%$ & $27,5 \%$ & $6,3 \%$ \\
\hline $\begin{array}{l}\text { U ovoj ustanovi omogućeno } \\
\text { mi je neograničeno slanje i } \\
\text { primanje pisama i paketa. }\end{array}$ & $3,8 \%$ & $3,8 \%$ & $3,8 \%$ & $10 \%$ & $72,3 \%$ & $6,3 \%$ \\
\hline $\begin{array}{l}\text { U ovoj ustanovi omogućeno } \\
\text { mi je slobodno korištenje } \\
\text { mobitela ili telefona. }\end{array}$ & $0 \%$ & $10 \%$ & $1,3 \%$ & $8,7 \%$ & $71,3 \%$ & $8,7 \%$ \\
\hline $\begin{array}{l}\text { U ovoj ustanovi omogućeno } \\
\text { mi je gledanje televizije ili } \\
\text { slušanje radijskih programa. }\end{array}$ & $0 \%$ & $3,8 \%$ & $2,5 \%$ & $7,5 \%$ & $81,2 \%$ & $5 \%$ \\
\hline
\end{tabular}

58 O lošim higijenskim uvjetima u sanitarnim čvorovima govore i ispitanici u svojim komentarima ističući kako bi „sanitarni čvorovi, tj. WC-i i tuševi trebali biti čišći“ i kako „toalet papir si sami trebamo nabavljati“. Rezultati provedenog istraživanja i komentari ispitanika pokazuju kako se još uvijek nisu uspjeli ispraviti loši uvjeti u sanitarnim čvorovima na koje je upozorila i Pučka pravobraniteljica u svom Izvješću o ljudskim pravima osoba s duševnim smetnjama u psihijatrijskim ustanovama u okviru djelovanja Nacionalnog preventivnog mehanizma u 2014. godini, op. cit., str. 9.-10.

59 Europski sud za ljudska prava već je u velikom broju slučajeva upozorio kako neodgovarajući smještajni uvjeti u psihijatrijskim ustanovama mogu predstavljati ponižavajuće postupanje, protivno članku 3. Europske konvencije za zaštitu ljudskih prava i temeljnih sloboda. Vidi primjerice: ESLJP, Stanev protiv Bugarske, zahtjev br. 36760/06 od 17. siječnja 2012.; G. protiv Francuske, zahtjev br. 27244/09 od 23. veljače 2012.; Rupa protiv Rumunjske, zahtjev br. 58478/00 od 16. prosinca 2008.; Romanov protiv Rusije, zahtjev br. 63993/00 od 20. listopada 2005. 
Primanje posjeta tijekom boravka u psihijatrijskoj ustanovi iznimno je važno pravo psihijatrijskih pacijenata. Liječenje u bolničkoj strukturi trebalo bi biti samo privremeno razdoblje u životu liječene osobe koja, nakon povratka u zajednicu, treba nastaviti funkcionirati u interakciji socijalnih veza koje je ostvarila prije prijema u ustanovu. Stoga je održavanje veza s obitelji, prijateljima i kolegama tijekom hospitalizacije bitan preduvjet za poboljšanje izgleda za psihosocijalnu rehabilitaciju, očuvanje remisije i uspješnost liječenja u postotpusnom razdoblju. Prema podatcima iz tablice 9. samo su dvadeset dva ispitanika iskazala kako svakoga tjedna bez iznimke primaju posjete.$^{60} \mathrm{No}$, isto se toliko pacijenata uključenih u istraživanje izjasnilo kako nisu nikada imali tjedne redovite posjete. I brojna su druga istraživanja pokazala kako je izostanak posjeta psihijatrijskim pacijentima usko povezan s njihovom velikom stigmatizacijom, ali i preopterećenošću obitelji koja skrbi o oboljelima. Čini se opravdanim pretpostaviti da na izostanak redovitih posjeta utječe i dislociranost psihijatrijskih ustanova u kojima je provedeno istraživanje.

Zbog svega navedenoga ne iznenađuje podatak da 15 ispitanika (18,7\%) rijetko prima redovite posjete. U samo $13,7 \%$ slučajeva psihijatrijske pacijente često se $\mathrm{i}$ redovito posjećuje. Na pitanje o učestalosti posjeta petoro ispitanika je odgovorilo „ne znam“. Kod jednakog broja ispitanika ostalo je nepoznato ostvaruju li i u kolikoj mjeri ovo pravo. Koji su to razlozi zbog kojih su pacijenti odlučili uskratiti svoje odgovore, može se samo pretpostaviti. Kako je u trenutku provođenja istraživanja trinaest ispitanika boravilo u psihijatrijskoj ustanovi manje od mjesec dana, moguće je da nisu niti bili u prilici ocijeniti učestalost i redovitost posjeta. Isto tako ostaje vjerojatnim da je do izostanka odgovora došlo jer se kod dugogodišnjih pacijenata doživljavanje vremena prilagodilo jednoličnoj bolničkoj svakodnevici, pa su dani prerasli u tjedne, a tjedni u mjesece, što je dovelo do nemogućnosti realne procjene učestalosti posjeta. ${ }^{61}$ Nadalje, moguće je da je izostanak odgovora jedan od načina kako se ispitanici distanciraju od bolničke stvarnosti i činjenice da ih se rijetko ili nikako posjećuje.

Za razliku od redovitoga primanja posjeta, drugi segmenti prava na doticaj s vanjskim svijetom nisu pokazali zabrinjavajuće rezultate. Naime, više od dvije trećine ispitanika uvijek može neograničeno slati i primati pismena (pedeset osam ispitanika), koristiti mobitel ili telefon (pedeset sedam ispitanika) odnosno pratiti televizijske i radijske programe (šezdeset pet ispitanika). U ostalim odgovorima na postavljena pitanja nisu uočene neke bitne razlike osim kod odgovora o potpunoj isključenosti komunikacije putem mobitela i telefona. Naime, osam pacijenata je odgovorilo kako

60 Na otežanu komunikaciju s vanjskim svijetom, osim neredovitoga primanja posjeta, uvelike utječe i činjenica da se pacijentima ograničeno dopušta boraviti izvan psihijatrijske ustanove. Prema osobnom stajalištu ispitanika, problematično je što oni borave $u$,ustanovi zatvorenog tipa“, stoga „bi bilo poželjno da pacijent može cijeli vikend provesti kod kuće, ukoliko nije u lošem zdravstvenom stanju“.

61 O odvojenosti hospitaliziranih psihijatrijskih pacijenata od ostatka svijeta slikovito govori rečenica da „... dok su u ustanovi, pacijenti su u nekoj vrsti mjehura.“ Owen-Smith, A. i dr.: „When You're in the Hospital, You're in a Sort of Bubble.“ Understanding the High Risk of Self-Harm and Suicide Following Psychiatric Discharge: A Qualitative Study, Crisis, vol. 35, br. 3, 2014., str. 154.-160. 
nikada ne mogu slobodno koristiti ove uređaje. Dobiveni rezultati u skladu su s podacima iz Izvješća Pučke pravobraniteljice o ljudskim pravima osoba s duševnim smetnjama u psihijatrijskim ustanovama o ograničenom korištenju telekomunikacijskih uređaja. Naime, u Izvješću je zabilježeno kako se branilo pacijentima korištenje osobnih mobitela. Pozive su mogli primati na telefonu na odjelu, a slati samo s telefona socijalne radnice $\mathrm{u}$ vrijeme njezina boravka u psihijatrijskoj ustanovi. ${ }^{62}$ Potpuni ili djelomični izostanak prava na korištenje telekomunikacijskih uređaja postaje pretjeranim opterećenjem za svakoga psihijatrijskog pacijenta, posebice ako je hospitaliziran u dislociranoj bolničkoj ustanovi, a rijetko prima posjete. Takvi slučajevi uvelike odstupaju od uvriježenih rješenja dobre prakse kojima se nastoji postići suprotno. Poticanjem komunikacije psihijatrijskih pacijenata s osobama koje ne pripadaju uskom bolničkom krugu, neposredno tijekom posjeta ili posredno putem tehničkih uređaja, nastoje se umanjiti ograničenja prava na poštovanje osobnog života pacijenata koje neminovno povlači svaka hospitalizacija.

Tablica 10. Ostala prava psihijatrijskih pacijenata

\begin{tabular}{|l|c|c|c|c|c|c|}
\hline & Ne znam & Nikad & Rijetko & Često & Uvijek & Nepoznato \\
\hline $\begin{array}{l}\text { U ovoj ustanovi mogu } \\
\text { sudjelovati u vjerskim i } \\
\text { kulturnim aktivnostima. }\end{array}$ & $2,5 \%$ & $2,5 \%$ & $2,5 \%$ & $5 \%$ & $82,5 \%$ & $5 \%$ \\
\hline $\begin{array}{l}\text { Kada obavim neki posao za } \\
\text { ovu psihijatrijsku ustanovu, } \\
\text { primim naknadu u novcu. }\end{array}$ & $23,7 \%$ & $40 \%$ & $2,5 \%$ & $5 \%$ & $22,5 \%$ & $6,3 \%$ \\
\hline $\begin{array}{l}\text { U ovoj ustanovi omogućeno } \\
\text { mi je glasovanje na lokalnim } \\
\text { i parlamentarnim izborima. }\end{array}$ & $25 \%$ & $22,5 \%$ & $2,5 \%$ & $5 \%$ & $38,7 \%$ & $6,3 \%$ \\
\hline $\begin{array}{l}\text { U ovoj ustanovi na pritužbe } \\
\text { dobivam odgovore. }\end{array}$ & $5 \%$ & $5 \%$ & $5 \%$ & $22,5 \%$ & $56,2 \%$ & $6,3 \%$ \\
\hline $\begin{array}{l}\text { U ovoj ustanovi bolničko } \\
\text { osoblje pomaže mi u } \\
\text { osiguranju preduvjeta da se } \\
\text { nakon otpusta mogu vratiti u } \\
\text { moju zajednicu. }\end{array}$ & $2,5 \%$ & $7,5 \%$ & $1,3 \%$ & $15 \%$ & $68,7 \%$ & $5 \%$ \\
\hline
\end{tabular}

Tijekom provođenja istraživanja posebno se željelo provjeriti koliko se ostvaruju neka druga prava psihijatrijskih pacijenata koja su zagarantirana ZZODSom, no ne mogu se razvrstati u prethodno navedene kategorije prava osoba s duševnim smetnjama. Primjerice, prikupili su se podatci o vjerskim i kulturnim slobodama ispitanika tijekom bolničkoga liječenja. Analiza dobivenih odgovora pokazuje kako je prihvaćanje vjerskog i kulturnog identiteta ispitanika jedno od najmanje spornih prava. ${ }^{63}$ Naime, 66 osoba $(82,5 \%)$ odgovorilo je kako uvijek mogu sudjelovati u

62 Republika Hrvatska, Pučki pravobranitelj: Izvješće o ljudskim pravima osoba s duševnim smetnjama u psihijatrijskim ustanovama u okviru djelovanja Nacionalnog preventivnog mehanizma u 2014. godini, op. cit., str. 16.

63 Dobiveni rezultati u skladu su sa zaključcima struke kako vjerska uvjerenja pacijenata imaju veliku važnost za postizanje pozitivnih rezultata u psihoterapiji. Pedroni, I.: Finding New Ways 
vjerskim i kulturnim aktivnostima tijekom boravka u psihijatrijskim ustanovama. Četvoro pacijenata ocijenilo je svoje sudjelovanje u vjerskim i kulturnim programima čestim. Dva ispitanika (2,5\%) rijetko ili nikad ne sudjeluje u takvim događanjima. Odgovor na postavljeno pitanje nije dobiven u četiri slučaja (5 \%).

Različiti su odgovori dani kod pitanja prava na novčanu naknadu pacijenata za rad obavljen za psihijatrijsku ustanovu. ${ }^{64}$ Iako su ravnatelji sve četiri psihijatrijske bolnice izjavili kako svi pacijenti primaju uglavnom novčanu nagradu za rad na radno-terapijskim poslovima, samo je osamnaest pacijenata $(22,5 \%)$ potvrdilo navedeno. Novčanu nagradu često je primalo samo četiri ispitanika (5\%), a rijetko dva $(2,5 \%)$. Čak $40 \%$ ispitanika nikada nije primilo naknadu za obavljene radne poslove u psihijatrijskoj ustanovi. Veliki je udio i onih koji nisu znali odgovoriti na postavljeno pitanje (23,7 \%). Budući da je čak $45 \%$ ispitanika u trenutku provođenja istraživanja boravilo u psihijatrijskoj ustanovi manje od tri mjeseca (36 ispitanika), vrlo je vjerojatno da nisu niti obavljali radno-terapijske zadatke, pa nisu niti mogli znati dobiva li se novčana naknada u psihijatrijskoj ustanovi ili ne. U svakom slučaju, odgovori ispitanika stvaraju sumnju na postojanje nedopuštenoga iskorištavanja rada psihijatrijskih pacijenata pa je u budućim istraživanjima potrebno nužno istražiti ostvarivost prava na naknadu za poslove obavljene za psihijatrijske ustanove. ${ }^{65}$

Pasivno biračko pravo psihijatrijskih pacijenata po prvi je puta izričito proklamirano u ZZODS-u iz 2014. godine. Radi se o novom pravu koje je u skladu s odredbom Zakona o registru birača, prema kojoj se biračima smatraju i osobe bez poslovne sposobnosti. ${ }^{66}$ Prema rezultatima provedenog istraživanja, pravo glasovanja uvijek ima trideset jedan ispitanik (38,7\%). Prema mišljenju četvorice ispitanika (5\%), psihijatrijska ustanova pacijentima često osigurava pravo sudjelovanja na izborima. Upola manje ispitanika vjeruje kako je ostvarivanje biračkog prava u psihijatrijskoj ustanovi u kojoj borave rijetkost. Pet pacijenata (6,3\%) nije odgovorilo na postavljeno pitanje, a njih dvadeset $(25 \%)$ od ponuđenih je odgovora odabralo opciju „ne znam“. Visoki udio onih koji nisu znali odgovoriti na ovo pitanje i koji su odlučili ne odgovoriti može biti rezultat činjenice da nisu ni upoznati s tim pravom ili da zbog kratkoće boravka u ustanovi nisu niti mogli ocijeniti koliko psihijatrijska bolnica ispunjava svoju dužnost osiguranja pasivnoga biračkog prava pacijentima jer se tijekom njihovog smještaja izbori nisu niti održavali. Nužno je uzeti u obzir i činjenicu da je pravo glasovanja priznato i osobama koje su u potpunosti lišene poslovne sposobnosti tek od 29. prosinca 2012. godine.

Podatci iz tablice 10. upućuju na zaključak o visokoj razini aktivnog postupanja psihijatrijskog osoblja kod iznošenja pritužbi pacijenata. Više od tri četvrtine ispitanika

of Belonging Through Religious Experience in the Framework of a Therapeutic Encounter, International Journal of Psychoanalytic Self Psychology, vol. 10, 2015., str. 343.-354.

64 Više o oblicima, učincima i ulozi rada kod osoba s duševnim smetnjama vidi u: Laws, J.: 'Recovery Work' and 'Magic' among Long-Term Mental Health Service-Users, The Sociological Review, vol. 61, 2013., str. 344.-362.

65 Osim prava na naknadu za obavljeni rad, jedan od problema su i loši radni uvjeti u ustanovi. Tako npr. jedan ispitanik navodi kako je on kao ,aktivan sudionik u okupacijskoj radnoj terapiji, vanjski dio (parkovi) u prijepodnevnom terminu... vani i po vrućini, zimi, poledici i snijegu“.

66 Čl. 64. Zakona o registru birača, NN 144/12., 105/15. 
(78,7 \%) uvijek ili često dobije odgovor na pritužbu. Na iskazano nezadovoljstvo zbog proživljenog iskustva tijekom boravka u psihijatrijskoj ustanovi osam ispitanika nikada nije ili je rijetko dobilo odgovor. Četiri ispitanika odlučilo se za opciju „ne znam" dok pet njih nije odgovorilo na ovo pitanje.

U posljednjem pitanju iz upitnika nastojalo se utvrditi kakvo je osobno iskustvo ispitanika u ostvarivanju njihovog prava na podršku za život u zajednici. Čak pedeset pet ispitanika $(68,7 \%)$ smatra kako im bolničko osoblje uvijek pomaže u osiguranju preduvjeta za povratak u zajednicu. Visok je broj i onih koji vjeruju da su takve aktivnosti bolničkog osoblja učestale (12 ispitanika, odnosno $15 \%$ ). O rijetkim i nikakvim naporima bolničkog osoblja govori $8,8 \%$ ispitanika. Dva ispitanika nije znalo odgovoriti na ovo pitanje, a četiri ispitanika nije odgovorilo. Prikupljeni odgovori sudionika u istraživanju ukazuju na visoku uključenost bolničkog osoblja u pružanju podrške pacijentima da nakon otpusta nastave živjeti u zajednici. Pružanje podrške ključan je segment cjelovitoga pristupa liječenja psihijatrijskih pacijenata, koje ne prestaje izlaskom pacijenta iz psihijatrijske ustanove. Učinci postignuti tijekom terapije unutar bolnice zadržat će se i produbiti te dosegnuti rehabilitacijske ciljeve jedino ako se pacijentu osiguraju uvjeti za funkcionalan život u zajednici. Drugim riječima, pravo na podršku pri povratu u zajednicu ključan je faktor smanjenja vjerojatnosti rehospitalizacije. ${ }^{67}$ Pritom treba imati na umu kako je na putu ostvarivanja toga prava, angažman djelatnika psihijatrijske ustanove tek početna aktivnost $\mathrm{u}$ čije se provođenje moraju uključiti obitelj otpuštenog pacijenta te mnoge druge državne institucije. Naime, uspješno osigurana podrška zajednice jedan je od mogućih putova koji vode ostvarivanju načela deinstitucionalizacije.

\section{ZAKLJUČ AK}

Odgovori iz anketnih upitnika i onih koje su ispunjavali ravnatelji istraživanih psihijatrijskih ustanova i onih koje su ispunjavali njihovi pacijenti, ponudili su obilje zanimljivih sadržaja kojima se možemo donekle približiti svrsi istraživanja, tj. spoznaji razine zaštite prava osoba $s$ duševnim smetnjama u psihijatrijskim ustanovama $i$ uvjeta njihovog liječenja. Namjerno je upotrijebljen izraz „donekle približiti“ jer se istraživanje provodilo u samo četiri psihijatrijske ustanove, Vrapče, Popovača, Rab i Ugljan, koje su ujedno i jedine četiri ustanove u Republici Hrvatskoj, koje u svom sastavu imaju i forenzičke odjele. Uzorak je obuhvatio ukupno 80 psihijatrijskih pacijenata, što se s obzirom na čak dva selektivna „filtera“ (sposobnost pacijenata ne samo da odgovore na pitanja, već i da suptilno gradiraju procjene vlastitih situacija te dobrovoljnost njihovog sudjelovanja), može smatrati zadovoljavajućim uzorkom.

Pored toga, kada god se radi o istraživanjima koja se provode unutar zatvorenih

67 Rezultati velike većine istraživanja upućuju na zaključak kako se osobe koje kronično pate od duševnih smetnji moraju nositi s lošim bračnim stanjem, niskim položajem u društvenoj hijerarhiji, nemogućnošću da zadrže zaposlenje i hospitalizacijama dužim od devedeset dana. (Guimón, J.: Prejudice and Realities in Stigma, International Journal of Mental Health vol. 39, br. 3, 2010., str. 29.) Takve negativne karakteristike, pogotovo ako nisu ublažene naporima psihijatrijskog osoblja da se pacijentima osiguraju odgovarajući životni uvjeti nakon otpusta iz psihijatrijske klinike, pojačano utječu na povišenje izgleda za novom hospitalizacijom. 
institucija $\mathrm{u}$ analizi dobivenih rezultata treba biti posebno oprezan. Naime, $\mathrm{u}$ ustanovama u kojima pravila uvelike određuju ili ograničavaju slobodu ponašanja, u kojima suživot sa svima drugima, i pacijentima i zdravstvenim osobljem, ovisi o poštovanju tih pravila, a poboljšanje njihovoga zdravstvenog stanja ovisi o pomoći drugih, u kojima odluke o prisilnom liječenju i boravku u ustanovi donose drugi, u kojima je prisutan osjećaj nemoći, ovisnosti, neizvjesnosti i bespomoćnosti, nije realno očekivati potpunu otvorenost $i$ iskrenost, čak $i$ ako je riječ o ispunjavanju anonimnih upitnika. Štoviše, treba računati s određenom dozom nepovjerenja, pa i sumnje prema istraživačima, nepoznatim osobama koje su tek kratkotrajne pridošlice iz „,vanjskog svijeta“. Stoga je to možda jedan od razloga zašto su ovakva istraživanja u kojima se neposredno anketiraju psihijatrijski pacijenti iznimno rijetka.

Unatoč navedenom, i uz sva ranije spomenuta metodološka ograničenja ne treba zanemariti „iskustvo vlastite kože“ koje je bez obzira na naglašenu subjektivnost vrlo autentičan izvor spoznaja. Stoga se može reći da je najbolji način da se sazna poštuju li se i koliko prava zagarantirana ZZODS-om, postaviti to pitanje pacijentima u psihijatrijskim ustanovama.

Kako se iz prikaza rezultata istraživanja uočava, odgovori pacijenata o njihovim pravima vrlo su različiti. I to je već samo po sebi problematično. Naime, ovdje nije riječ o pravima koje osobama $s$ duševnim smetnjama smještenim u psihijatrijskoj ustanovi netko treba dati. To su prava koje psihijatrijski pacijenti imaju po zakonu, a na psihijatrijskim ustanovama je zakonska obveza da ta prava osiguraju. Štoviše, svako neosiguravanje prava osoba s duševnim smetnjama povlači za sobom prekršajnu odgovornost, odnosno novčano kažnjavanje psihijatrijske ustanove i odgovorne osobe. Stoga činjenica da je dio pacijenata na pitanja o poštovanju njihovih prava dao negativne odgovore nameće zaključak o zanemarivanju ili uskraćivanju prava osoba s duševnim smetnjama u istraživanim psihijatrijskim ustanovama. Sasvim jednostavno rečeno, sve osobe s duševnim smetnjama već kod prijema u psihijatrijsku ustanovu moraju biti upoznate sa svim svojim pravima, s razlozima i ciljevima smještaja $u$ psihijatrijsku ustanovu i kada to zatraže moraju dobiti uvid u svoju medicinsku dokumentaciju. Isto tako, medicinski postupci prema njima ne smiju se primjenjivati bez njihova informiranog pristanka (osim ako je riječ o prisilnim hospitalizacijama forenzičkih pacijenata), čime im se osigurava da sudjeluju u planiranju i provođenju svoga liječenja. Pravo na održavanje kontakata (komunikaciju putem posjeta, pisama, telefoniranja) i pravo na praćenje informacija (korištenjem novina, knjiga, televizije, radija) u današnje je vrijeme neupitno pravo svake osobe koja se zadržava u nekoj ustanovi, pod uvjetom da ih ne zloupotrebljava.

Sva ova, ali i mnoga druga ZZODS-om zagarantirana prava psihijatrijskih pacijenata u funkciji su čuvanja njihovog dostojanstva, autonomije, samoodređenja, jer ih se njihovim ostvarivanjem tretira kao subjekte koji kada god to mogu i u mjeri u kojoj mogu donose odluke o svome zdravlju. U ovom kontekstu nepotrebno je baviti se pitanjem zašto svi pacijenti ta prava ne mogu ostvariti jer zakon od trenutka kada stupi na snagu ne daje ovlaštenje adresatima normi da odlučuju o njemu ili da selektivno primjenjuju neke njegove odredbe, već da ga dok je na snazi izvršavaju. Porazna je činjenica da navedena prava u Republici Hrvatskoj postoje još od davne 
1998., a ovo je istraživanje potvrdilo da se i nakon gotovo dvadeset godina zakonom zagarantiranim pravima pacijenata pristupa uglavnom samo formalno, što je u suprotnosti sa smislom i duhom samog ZZODS-a.

Premda su ispitanici dali različite odgovore vezane uz uvjete boravka i liječenja u psihijatrijskim ustanovama, oni su potpuno očekivani i opravdani. Riječ je o stavovima, procjenama, percepcijama, subjektivnim iskustvima koji kod svake osobe mogu biti drukčiji. Ovdje činjenica da većina pacijenata izražava zadovoljstvo medicinskim osobljem, prije svega njihovim odnosom prema njima, ali i brigom o njihovom zdravlju igra veliku ulogu. Nisu zanemarivi ni odgovori koji pokazuju da je veći dio pacijenata zadovoljan smještajnim uvjetima u ustanovama.

Ove odgovore treba svakako povezati s odgovorima koje su u Općem upitniku davali ravnatelji ovih ustanova. Iako se radi o vrlo različitim ustanovama, po brojnim parametrima (smještajnoj lokaciji, veličini prostora kojeg zauzimaju, broju paviljona, odnosno odjela, predviđenim kapacitetima, popunjenosti pacijentima, broju zaposlenika, sigurnosnim uvjetima itd.) većina njihovih odgovora u upitniku je gotovo identična ili su razlike u odgovorima minimalne. Tako se iz odgovora može zaključiti da niti jedna od istraživanih psihijatrijskih ustanova po pitanju prostornih i kadrovskih uvjeta ne ispunjava standarde propisane, već ranije spomenutim, Pravilnikom o minimalnim uvjetima u pogledu prostora, radnika i medicinsko-tehničke opreme za obavljanje zdravstvene djelatnosti.

Činjenica da unatoč naglašenoj kadrovskoj, prostornoj i opće poznatoj financijskoj problematici većina pacijenata istraživanih psihijatrijskih ustanova izražava zadovoljstvo uvjetima smještaja i odnosom medicinskog osoblja prema njima, sugerira zaključak o iznimnim naporima zaposlenika ovih ustanova da svojim pacijentima pruže što bolje uvjete boravka i liječenja unutar nedostatnih resursa.

Zaključno treba podsjetiti da postoje dva neupitna parametra koji pokazuju stvarni položaj osoba s duševnim smetnjama u psihijatrijskim ustanovama, pa i šire u društvenoj zajednici. Prvi parametar je poštovanje njihovih zakonom zagarantiranih prava, a drugi je uspješnost liječenja. Ovi parametri su međusobno snažno isprepleteni jer poštovanje prava pacijenata, njihovog dostojanstva, tretiranje kao ravnopravnih subjekata koji će sami ili uz pomoć zaposlenika donositi relevantne odluke o svom zdravlju, sasvim sigurno doprinosi njihovom liječenju. Isto tako, nema nikakve sumnje da dobri uvjeti smještaja u psihijatrijskim ustanovama mogu bitno pridonijeti uspješnoj primjeni terapije kod svakog pacijenta. Uspješnost liječenja koje se u današnjim uvjetima, još uvijek prisutnog institucionalnog liječenja, mjeri i duljinom boravka u psihijatrijskim ustanovama, temeljni je faktor u realizaciji uvodno opisanog načela deinstitucionalizacije. Nadalje, realizacija deinstitucionalizacije najjača je karika u rješavanju najtvrdokornijega problema kojeg osobe s duševnim smetnjama, nažalost još i danas trpe, problema stigmatizacije.

Ovaj pozitivni pravac koji polazi od poštovanja prava psihijatrijskih pacijenata i dobrih uvjeta njihovog liječenja, a vodi uspješnom liječenju, kratkotrajnim boravcima u psihijatrijskim ustanovama i završava deinstitucionalizacijom i destigmatizacijom osoba s duševnim smetnjama, može ići i u potpuno suprotnom smjeru. Loši uvjeti u psihijatrijskim ustanovama uz zanemarivanje ili nepoštovanje temeljnih prava 
psihijatrijskih pacijenata sasvim sigurno usporava ili čak i onemogućava njihovo uspješno liječenje te tako produljuje njihov boravak u ustanovama i jača stigmu opasnih pacijenata.

U kojem pravcu će hrvatsko društvo ići ovisi o brojnim faktorima, ali ponajprije o pozornosti koju će posvetiti psihijatrijskim pacijentima koje mnogi smatraju jednom od najranjivijih društvenih skupina. Rezultati provedenog istraživanja potvrđuju da se osobe s duševnim smetnjama, ali i psihijatrijske ustanove još uvijek nalaze na marginama društvenog interesa. To i nije novi zaključak. Riječ je o općepoznatoj činjenici. Međutim, ovog puta ta činjenica proizlazi izravno, ne samo iz pisanih odgovora ravnatelja psihijatrijskih ustanova koji niz godina uporno ukazuju na marginalnu društvenu poziciju svojih ustanova, već i njihovih pacijenata, odnosno osoba zbog kojih psihijatrijske ustanove, njihovi zaposlenici, ali i psihijatrija kao znanstvena disciplina uopće, i postoje.

\section{LITERATURA}

1. Burren, E.: Theorien der Strafe und Probleme des modernen Strafvollzuges, Kriminalistisches Institut des Kantons Zürich, Lenzburg, 1963.

2. Counts, N.: Accommodating One Another: Law and the Social Model of Mental Health, Kansas Journal of Law \& Public Policy, vol. 25, br. 1, 2015., str. 1.-30.

3. Di Petta, G.: C'era una volta il manicomio: dal diario di un giovane medico, Edizioni Unversitarie Romane, Roma, 2014.

4. Eaton, N., R. i dr.: An Invariant Dimensional Liability Model of Gender Differences in Mental Disorder Prevalence: Evidence From a National Sample, Journal of Abnormal Psychology, vol. 121, br. 1, 2012., str. 282.-288.

5. ESLJP, G. protiv Francuske, zahtjev br. 27244/09 od 23. veljače 2012.; Romanov protiv Rusije, zahtjev br. 63993/00 od 20. listopada 2005.; Rupa protiv Rumunjske, zahtjev br. 58478/00 od 16. prosinca 2008.; Stanev protiv Bugarske, zahtjev br. 36760/06 od 17. siječnja 2012.

6. Flowers, N.: The Human Rights Education Handbook, Effective Practices for Learning, Action, and Change, The Human Rights Resource Center University of Minnesota, The Stanley Foundation, Minneapolis, 2000.

7. Giel, R.: The Jigsaw Puzzle of Dutch Mental Health Care, International Journal of Mental Health, vol. 16, br. 1/2, 1987., str. 152.-163.

8. Glesinger, L.: Povijest psihijatrije u Hrvatskoj, Pretisak doktorske disertacije, objavljeno u: Pećina, M. i Fatović-Ferenčić, S. (ur.): Ludnica i lučbarnica, Razvoj laboratorija u psihijatrijskoj bolnici, Rasprave i građa za povijest znanosti, Knjiga 12, Hrvatska akademija znanosti i umjetnosti, Zagreb, 2012., str. 18.-88.

9. Goreta, M.: Errare humanum est, Najčešće pogreške u forenzičko-psihijatrijskoj praksi, Naklada Slap, Jastrebarsko, 2015.

10. Gostin, L., O. i Gable, L.: The Human Rights of Persons with Mental Disabilities: A Global Perspective on the Application of Human Rights Principles to Mental Health, Maryland Law Review, vol. 63, 2004., str. 20.-121.

11. Grozdanić, V. (ur.): Komentar Zakona o zaštiti osoba s duševnim smetnjama, Pravni fakultet Sveučilišta u Rijeci, Rijeka, 2015.

12. Guimón, J.: Prejudice and Realities in Stigma, International Journal of Mental Health vol. 39, br. 3, 2010., str. 2.-43.

13. Howard, J.: The State of Prisons in England and Wales with Preliminary Observations and an Account of Some Foreign Prisons and Hospitals, William Eyres, Warrington, 1777. 
14. Hrvatski zavod za javno zdravstvo: Izvješće o osobama s invaliditetom u Republici Hrvatskoj, Zagreb, 2007., 2017.

15. Hrvatski zavod za zdravstveno osiguranje, Ugovoreni sadržaji bolničke zdravstvene zaštite za 2017. godinu, postelje, specijalističke ordinacije, dijagnostičke jedinice mjesta dnevne bolnice 2017., objavljeno na: <http://www.hzzo.hr/>, zadnji put posjećeno 10 . svibnja 2017.

16. Human Rights Council, Report of the Special Rapporteur on the right of everyone to the enjoyment of the highest attainable standard of physical and mental health, A/ HRC/35/21, 28. ožujka 2017.

17. Isaac, R. J., Armat, V. C.: Madness in the Streets: How the Psychiatry and the Law Abandoned the Mentally Ill, Free Press, New York, 1990.

18. Jukić, V.: Bolnica Vrapče kao odraz društvene stvarnosti: pogled jednog ravnatelja, objavljeno u: Pećina, M. i Fatović-Ferenčić, S. (ur.), Ludnica i lučbarnica, Razvoj laboratorija u psihijatrijskoj bolnici, Rasprave i građa za povijest znanosti, Knjiga 12, Hrvatska akademija znanosti i umjetnosti, Zagreb, 2012., str. 89.-97.

19. Kessler, R. C. i dr.: The Social Consequences of Psychiatric Disorders, III: Probability of Marital Stability, American Journal of Psychiatry, vol. 155, br. 8, 1998., str. 1092.1096.

20. Konvencija o pravima osoba s invaliditetom, NN-MU 6/07., 3/08., 5/08.

21. Kopel, D. B. i Cramer, C. E.: Reforming Mental Health Law to Protect Public Safety and Help the Severely Mentally Ill, Howard Law Journal, vol. 58, 2014., str. 715.-778.

22. Kovač, M.: Sedamdeset i pet godina neuropsihijatrijske bolnice, objavljeno na: $<$ http:// www.psihoportal.com/index.php/hr/en/vijesti/416-75-godina-neuropsihijatrijskebolnice>, zadnji put posjećeno 10. svibnja 2017.

23. Längle, G. i dr.: Indicators of Quality of In-Patient Psychiatric Treatment: The Patients' View, International Journal for Quality in Health Care, vol. 15, br. 3, 2003., str. 213.221.

24. Laws, J.: 'Recovery Work' and 'Magic' among Long-Term Mental Health ServiceUsers, The Sociological Review, vol. 61, 2013., str. 344.-362.

25. Legge 13 maggio 1978, n. 180. (Legge Basaglia)

26. Mahmoud, A. S. i dr.: Relationship between Social Support and the Quality of Life among Psychiatric Patients, Journal of Psychiatry and Psychiatric Disorders, vol. 1, br. 2., 2017., str. 59.-66.

27. Mental Disability Advocacy Center, Udruga Sjaj: Daleko od očiju, Ljudska prava u psihijatrijskim bolnicama i ustanovama socijalne skrbi u Hrvatskoj, Budimpešta, Zagreb, 2011.

28. Mental Retardation Facilities and Community Mental Health Centers Construction Act, Public Law 88-164, 77 STAT 282.

29. Mimica, N.: Otvorena Spomen-biblioteka u Klinici za psihijatriju Vrapče, Mef.hr: list Medicinskog fakulteta Sveučilišta u Zagrebu, vol. 30, br. 2, 2011., str. 105.

30. Nacionalna klasifikacija zanimanja 2010. - NKZ 10., NN 147/10.

31. Norcio, B.: Care for Mentally Ill in Italy, BMJ, vol. 306, 1993., str. 1615.-1616.

32. Opća deklaracija o ljudskim pravima, NN-MU 12/09.

33. Owen-Smith, A. i dr.: „When You're in the Hospital, You're in a Sort of Bubble.“ Understanding the High Risk of Self-Harm and Suicide Following Psychiatric Discharge: A Qualitative Study, Crisis, vol. 35, br. 3, 2014., str. 154.-160.

34. Pedroni, I.: Finding New Ways of Belonging Through Religious Experience in the Framework of a Therapeutic Encounter, International Journal of Psychoanalytic Self Psychology, vol. 10, 2015., str. 343.-354.

35. Perlin, M. L.: International Human Rights and Institutional Forensic Psychiatry: The Core Issues, objavljeno u: Völlm, B., Nedopil, N. (ur.): The Use of Coercive Measures in Forensic Psychiatric Care, Legal, Ethical and Practical Challenges, Springer International Publishing, Cham, 2016., str. 9.-29. 
36. Player, C. T.: Involuntary Outpatient Commitment: The Limits of Prevention, Stanford Law and Policy Review, vol. 26, 2015., str. 159.-238.

37. Poreddi, V. i dr.: People with Mental Illness and Human Rights: A Developing Countries Perspective, Indian Journal of Psychiatry, vol. 55, br. 2, 2013., str. 117.-124.

38. Poredoš Lavor, D. i dr.: Dnevna bolnica: društveno-medicinska sadašnjost i budućnost, Ljetopis socijalnog rada, vol. 15, br. 2, 2008., str. 323.-332.

39. Potter, N.: The Virtue of Defiance and Psychiatric Engagement, Oxford University Press, Oxford, 2016.

40. Pravilnik o listama psihijatrijskih ustanova koje ispunjavaju uvjete za smještaj i liječenje djece odvojeno od punoljetnih osoba, NN 76/14.

41. Pravilnik o listi psihijatrijskih ustanova za prisilni smještaj neubrojivih osoba i psihijatrijskih ustanova u kojima se neubrojive osobe liječe na slobodi, NN 76/14.

42. Pravilnik o minimalnim uvjetima u pogledu prostora, radnika i medicinsko-tehničke opreme za obavljanje zdravstvene djelatnosti, NN 61/11., 128/12., 124/15., 8/16.

43. Republika Hrvatska, Pučki pravobranitelj: Izvješće o ljudskim pravima osoba s duševnim smetnjama u psihijatrijskim ustanovama u okviru djelovanja Nacionalnog preventivnog mehanizma u 2014. godini, Zagreb, 2015.

44. Republika Hrvatska, Pučki pravobranitelj: Izvješće Pučke pravobraniteljice za 2015. i 2016. godinu, Zagreb, 2016.-2017.

45. Roberts, N., Stuart, H. i Lam, M.: High School Mental Health Survey: Assessment of a Mental Health Screen, La Revue canadienne de psychiatrie, vol. 53, br. 5, 2008., str. 314.-322.

46. Santone, G. i dr.: The Process of Care in Residential Facilities - A National Survey in Italy, Social Psychiatry \& Psychiatric Epidemiology, vol. 40, br. 7, 2005., str. 540.-350.

47. Schröder, A. i dr.: Patients' Perceptions of the Concept of the Quality of Care in the Psychiatric Setting: A Phenomenographic Study, Journal of Clinical Nursing, vol. 15, br. 1, 2006., str. 93.-102.

48. Starr, P.: The Social Transformation of American Medicine, The Rise of Sovereign Profession and the Making of a Vast Industry, Basic Books, New York, 1982.

49. Šendula-Jengić, V., Juretić, I. i Hodak, J.: Psychiatric Hospital - From Asylums to Centres for Mind-Body Wellness, Collegium Antropologicum, vol. 35, br. 4, 2011., str. 978.-988.

50. The Center for Collegiate Mental Health: 2016 Annual Report, Penn State University, University Park, 2017.

51. The Council of Europe: The CPT Visits Croatia, objavljeno na: $<$ http://www.coe.int/en/ web/cpt/-/the-cpt-visits-croatia>, zadnji put posjećeno 10. svibnja 2017.

52. Van Hoof, F. i dr.: The Role of National Policies and Mental Health Care Systems in the Development of Community Care and Community Support: An International Analysis, Journal of Mental Health, vol. 24, br. 4, 2015., str. 202.-207.

53. Wagnitz, H., B.: Historische Nachrichten und Bemerkungen über die merkwürdigsten Zuchthäuser in Deutschland: Nebst einem Anhange über die zweckmässigste Einrichtung der Gefängnisse und Irrenanstalten, Johann Jacob Gebauer, 1791.

54. World Health Organization, Regional Committee for Europe: The European Mental Health Action Plan, Kopenhagen, 2013.

55. Zakon o registru birača, NN 144/12., 105/15.

56. Zakon o zaštiti osoba s duševnim smetnjama, NN 76/14.

57. Zakonski članak br. 58. o ustrojavanju javne ludnice za obseg Hrvatske i Slavonije, Sbornik zakonah i naredabah valjanih za Kraljevinu Hrvatsku i Slavoniju, godina 1873., komad XIX. 
Velinka Grozdanić*

Dalida Rittossa**

Summary

\section{THE RIGHTS OF PERSONS WITH MENTAL DIFFICULTIES IN PSYCHIATRIC INSTITUTIONS IN THE REPUBLIC OF CROATIA - AN EMPIRICAL ANALYSIS}

Nowadays, after reaching the numerous scientific conclusions in the field of mental health, it is evidently obvious that there is a direct link between the respect for rights of psychiatric patients and inpatient conditions on the one hand and patient treatment effectiveness, their deinstitutionalisation, and therefore, destigmatisation on the other. Nevertheless, in recent years, the reports delivered by the Ombudswoman and Disability Ombudswoman as well as numerous judgments of the European Court for Human Rights in cases of violation of rights of persons with mental difficulties are a clear warning about insufficient accommodation and treatment conditions in psychiatric institutions in the Republic of Croatia. Therefore, it proved justifiable to explore to what extent psychiatric patients exercise their rights as indoor patients and what are the conditions of their medical treatment. With this aim, the research was conducted at the Psychiatric Clinic „Vrapče“, Psychiatric Hospital Rab, Neuropsychiatric Hospital „Dr. Ivan Barbot“ Popovača and Psychiatric Hospital Ugljan, the only psychiatric hospitals in the Republic of Croatia with hospital wards designated for compulsory detention of mentally incapable defendants upon the decision of the criminal court. Two different questionnaires were disseminated, the Basic Questionnaire for Directors of Psychiatric Institutions and the anonymous questionnaire on the sample of 80 patients. The article presents the analysis of the results obtained from these two questionnaires.

Keywords: rights of psychiatric patients, psychiatric institutions, deinstitutionalisation.

* Velinka Grozdanić, Ph. D., Full Professor, Faculty of Law, University of Rijeka; velinka@ pravri.hr

** Dalida Rittossa, Ph. D., Assistant Professor, Faculty of Law, University of Rijeka; dalida@ pravri.hr 
Zussamenfassung

\section{RECHTE VON PERSONEN MIT SEELISCHEN STÖRUNGEN IN PSYCHIATRISCHEN ANSTALTEN DER REPUBLIK KROATIEN - EINE EMPIRISCHE ANALYSE}

Nachdem man im Bereich psychischer Gesundheit zu zahlreichen wissenschaftlichen Erkenntnissen gekommen ist, ist es heutzutage völlig klar, dass die Achtung der Rechte psychiatrischer Patienten und die Bedingungen derer Unterbringung in psychiatrischen Anstalten einerseits und der Erfolg in der Behandlung, Deinstitutionalisierung und Destigmatisierung von Patienten andererseits direkt miteinander verbunden sind. In den letzten Jahren aber weisen die Berichte der Bürgerbeauftragten und der Beauftragten für Behinderte sowie auch zahlreiche Urteile des Europäischen Gerichtshofs für Menschenrechte hinsichtlich der Beschwerden von Personen mit seelischen Störungen auf schlechte Bedingungen der Unterbringung und Behandlung von Patienten in psychiatrischen Anstalten der Republik Kroatien hin. Deshalb stellte sich als rechtfertigend heraus, das Ausmaß der Verwirklichung der Rechte psychiatrischer Patienten sowie auch die Bedingungen derer Behandlung zu erforschen. Zu diesem Zweck wurde die Forschung in der Klinik für Psychiatrie „Vrapče“, im psychiatrischen Krankenhaus Rab, im Neuropsychiatrischem Krankenhaus „Dr. Ivan Barbot“ Popovača und im Psychiatrischen Krankenhaus Ugljan durchgeführt, den einzigen psychiatrischen Krankenhäusern in der Republik Kroatien mit Abteilungen für schuldunfähige Personen, welchen nach der Entscheidung des Strafgerichts eine Verwahrung angeordnet wurde. Dabei wurden zwei Fragebögen benutzt: der Basisfragebogen für die Leiter von psychiatrischen Anstalten und der anonyme Fragebogen für eine Patientengruppe von 80 Patienten. Ziel dieser Arbeit ist es, die durch Fragebogen aufgezeigten Ergebnisse zu analysieren.

Schlüsselwörter: Rechte psychiatrischer Patienten, psychiatrische Anstalten, Deinstitutionalisierung. 


\section{Riassunto}

\section{DIRITTI DELLE PERSONE CON DISTURBI MENTALI NELLE STRUTTURE PSICHATRICHE NELLA REPUBBLICA DI CROAZIA - ANALISI EMPIRICA}

Oggigiorno, dopo avere raggiunto importanti traguardi nella scienza in ambito della salute mentale, è del tutto evidente l'esistenza di una diretta connessione tra il rispetto dei diritti dei pazienti psichiatrici e le condizioni di collocazione nelle strutture psichiatriche, da una parte, ed il successo nella cura dei pazienti, della loro deistituzionalizzazione e conseguente destigmatizzazione, dall'altra parte. Tuttavia, negli ultimi anni dal rapporto del Difensore civico e del Difensore delle persone con disabilità e dalla copiosa giurisprudenza della Corte europea dei diritti dell'uomo in casi dove vi sono reclami di persone con disabilità si evince che le condizioni di collocamento e cura nelle strutture psichiatriche nella Repubblica di Croazia non sono buone. Pertanto è apparso fondato intraprendere un'indagine circa la misura in cui i pazienti psichiatrici riescano ad esercitare i propri diritti nelle strutture psichiatriche, come pure circa le condizioni in cui versano durante le cure. A tale fine, è stata condotta una ricerca nella clinica psichiatrica „Vrapče“, nell'Ospedale psichiatrico Rab, nell'Ospedale neuropsichiatrico „Dr. Ivan Barbot“ Popovača e nell'Ospedale psichiatrico Ugljan, ovvero gli unici ospedali psichiatrici nella Repubblica di Croazia che all'interno della struttura hanno anche reparti dove sono collocate forzatamente persone incapaci d'intendere e volere in forza di una decisione del tribunale penale. Al riguardo sono stati utilizzati due questionari, il questionario di base per i dirigenti delle strutture psichiatriche ed un questionario anonimo per i pazienti, utilizzato su un campione di 80 intervistati. L'analisi dei risultati raccolti nei questionari costituiscono l'oggetto di questo lavoro.

Parole chiave: diritti dei pazienti psichiatrici, strutture psichiatriche, deistituzionalizzazione. 